\title{
The levels, variation characteristics, and sources of atmospheric non-methane hydrocarbon compounds during wintertime in Beijing, China
}

\author{
Chengtang Liu ${ }^{1,3, *}$, Zhuobiao Ma ${ }^{1,3,{ }^{*}}$, Yujing Mu${ }^{1,2,3,4}$, Junfeng Liu ${ }^{1,2,3}$, Chenglong Zhang ${ }^{1,2,3}$, Yuanyuan Zhang ${ }^{1,2,3}$, \\ Pengfei Liu ${ }^{1,3}$, and Hongxing Zhang ${ }^{1,5}$ \\ ${ }^{1}$ Research Center for Eco-Environmental Sciences, Chinese Academy of Sciences, Beijing 100085, China \\ ${ }^{2}$ Center for Excellence in Regional Atmospheric Environment, Institute of Urban Environment, \\ Chinese Academy of Sciences, Xiamen 361021, China \\ ${ }^{3}$ University of Chinese Academy of Sciences, Beijing 100085, China \\ ${ }^{4}$ National Engineering Laboratory for VOCs Pollution Control Material \& Technology, University of Chinese Academy of \\ Sciences, Beijing 100049, China \\ ${ }^{5}$ Beijing Urban Ecosystem Research Station, Beijing, 100085, China \\ *These authors contributed equally to this work.
}

Correspondence to: Yujing Mu (yjmu@ rcees.ac.cn)

Received: 30 August 2016 - Discussion started: 16 December 2016

Revised: 30 June 2017 - Accepted: 25 July 2017 - Published: 11 September 2017

\begin{abstract}
Atmospheric non-methane hydrocarbon compounds (NMHCs) were measured at a sampling site in Beijing city from 15 December 2015 to 14 January 2016 to recognize their pollution levels, variation characteristics, and sources. We quantified $53 \mathrm{NMHCs}$, and the proportions of alkanes, alkenes, acetylene, and aromatics to the total NMHCs were 49.8-55.8, 21.5-24.7, 13.5-15.9, and 9.3$10.7 \%$, respectively. The variation trends in the NMHC concentrations were basically identical and exhibited remarkable fluctuation, which was mainly ascribed to the variation in meteorological conditions, especially wind speed. The diurnal variations in NMHCs on clear days exhibited two peaks during the morning and evening rush hours, whereas the rush hours' peaks diminished or even disappeared on the haze days, implying that the relative contribution of the vehicular emissions to atmospheric NMHCs depended on the pollution status. Two evident peaks of the propane / propene ratios appeared in the early morning before sun rise and at noontime on clear days, whereas only one peak occurred in the afternoon during the haze days, which were attributed to the relatively fast reactions of propene with $\mathrm{OH}, \mathrm{NO}_{3}$, and $\mathrm{O}_{3}$. Based on the chemical kinetic equations, the daytime $\mathrm{OH}$ concentrations were calculated to be
\end{abstract}

in the range of $3.47 \times 10^{5}-1.04 \times 10^{6}$ molecules $\mathrm{cm}^{-3}$ on clear days and $6.42 \times 10^{5}-2.35 \times 10^{6}$ molecules $\mathrm{cm}^{-3}$ on haze days. The nighttime $\mathrm{NO}_{3}$ concentrations were calculated to be in the range of $2.82 \times 10^{9}-4.86 \times 10^{9}$ molecules $\mathrm{cm}^{-3}$ on clear days. The correlation coefficients of typical hydrocarbon pairs (benzene / toluene, o-xylene / m,p-xylene, isopentane / $\mathrm{n}$-pentane, etc.) revealed that vehicular emissions and coal combustion were important sources for atmospheric NMHCs in Beijing during the wintertime. Five major emission sources for atmospheric NMHCs in Beijing during the wintertime were further identified by positive matrix factorization (PMF), including gasoline-related emissions (gasoline exhaust and evaporation), coal combustion, diesel exhaust, acetylene-related emissions, and consumer and household products. Coal combustion (probably domestic coal combustion) was found to make the greatest contribution (29.6-33.4\%) to atmospheric NMHCs during haze days. 


\section{Introduction}

As an important class of volatile organic compounds (VOCs), non-methane hydrocarbons (NMHCs) play a pivotal role in atmospheric chemistry (Houweling et al., 1998; Rappenglück et al., 2014) and their degradation can cause formation of secondary products, such as ozone $\left(\mathrm{O}_{3}\right)$ and secondary organic aerosol (SOA), which affect oxidizing capacity, radioactive balance, and human health (Volkamer et al., 2006; Shen et al., 2013; Huang et al., 2014; Liu et al., 2015; Palm et al., 2016; La et al., 2016). NMHCs can originate either from biogenic or anthropogenic sources. Biogenic sources are mainly from emissions of vegetation and anthropogenic sources are related to fossil fuel combustion (vehicle exhaust, heat generation, and industrial processes), storage and distribution of fuels (gasoline, natural gas, and liquefied petroleum gas, LPG), and solvent use. Because the global emissions and the reaction activity of biogenic NMHCs are much greater than those of anthropogenic NMHCs (Goldstein and Galbally, 2007), atmospheric biogenic NMHCs (e.g., isoprene) are more important in the global atmospheric environment. In urban areas, however, anthropogenic NMHCs greatly exceed biogenic NMHCs and have been considered as one of the most dominant drivers of air pollution (Srivastava et al., 2005; Gaimoz et al., 2011; Waked et al., 2012). In addition, some anthropogenic NMHCs (e.g., benzene and 1,3-butadiene) have been verified to be toxic, carcinogenic, or mutagenic (US EPA, 2008; Møller et al., 2008). Due to the negative impact of NMHCs on the atmospheric environment as well as human health, atmospheric NMHC measurements have been conducted worldwide in many urban areas (Shirai et al., 2007; Gaimoz et al., 2011; Waked et al., 2016), and the results revealed that NMHCs made a remarkable contribution to atmospheric $\mathrm{O}_{3}$ and SOA in most cities and the cancer risk of benzene even exceeded the value of $1.0 \times 10^{-6}$ in some cities (Zhou et al., 2011; Du et al., 2014).

Beijing, as one of the world's megacities, has encountered two prominent atmospheric environmental problems: the elevation of near-surface $\mathrm{O}_{3}$ levels and the serious pollution of fine particles (including SOA), which result in frequent haze formation (Sun et al., 2014). Therefore, the levels and sources for atmospheric NMHCs in Beijing city have raised great concern (Song et al., 2007; Wu et al., 2016). More than 40 papers about NMHCs in Beijing city have been published since 1994 (Shao et al., 1994), and the results indicated that the concentrations of NMHCs in Beijing were significantly higher than those in the cities of most developed countries (Gros et al., 2007; Parrish et al., 2009). The major components of atmospheric NMHCs in Beijing city were found to be alkanes, alkenes, and aromatics, and the relatively high proportions of alkenes and aromatics have been suspected to be responsible for formation of $\mathrm{O}_{3}$ and SOA (Li et al., 2015; Sun et al., 2016). Based on the model of positive matrix factorization (PMF), several studies also investigated the ma- jor sources and their contributions to atmospheric NMHCs in Beijing city: transportation-related sources (32-46\%), paint and solvent use and industry (18-30\%), and solvent utilization $(8-14 \%)$ were found to be the major sources for atmospheric NMHCs in summer (Wang et al., 2015; Li et al., 2016), while vehicle exhaust (26-39\%) and coal combustion (35-41\%) were the dominant sources in winter (Wang et al., 2013). However, most studies mainly focused on summertime. The data of atmospheric NMHCs in Beijing city during wintertime were still sparse, e.g., only two reports about atmospheric NMHCs (Wang et al., 2012, 2013) and two reports about benzene, toluene, ethylbenzene, and xylene (Zhang et al., 2012a, b). To comprehensively evaluate the influence of atmospheric NMHCs on the air quality and to further identify the sources of atmospheric NMHCs in Beijing city, more measurements of atmospheric NMHCs in winter are still needed.

In this study, atmospheric NMHCs were measured online using a liquid-nitrogen-free gas-chromatography flame ionization detector (GC-FID) in Beijing city from 15 December 2015 to 14 January 2016. The objectives of this study are (1) to determine the concentration levels and variation characteristics of atmospheric NMHCs in Beijing during wintertime and (2) to identify the major sources for atmospheric NMHCs in Beijing during wintertime.

\section{Experimental}

\subsection{Sampling site description}

Air samples were collected on a rooftop ( $20 \mathrm{~m}$ above the ground level) at the Research Center for Eco-Environmental Sciences (RCEES, $40.0^{\circ} \mathrm{N}, 116.3^{\circ} \mathrm{E}$ ), which lies to the north of Beijing city between the 4 th and 5th ring roads. The sampling site is surrounded by some residential areas, campuses, and institutes. Detailed information about the sampling site was provided in our previous studies (Pang and Mu, 2006; Liu et al., 2009). The meteorological data, including temperature, wind speed, relative humidity (RH), visibility, and Air Quality Index of particulate matter with a diameter of less than $2.5 \mu \mathrm{m}\left(\mathrm{PM}_{2.5}\right)$, at RCEES were from a Beijing urban ecosystem research station, which is about $20 \mathrm{~m}$ away from our sampling site.

\subsection{Analytical methods}

Air samples were analyzed continuously and automatically using a custom-built liquid-nitrogen-free GC-FID online instrument, with a time resolution of $1 \mathrm{~h}$. The online instrument mainly consisted of a cooling unit, a sampling unit, a separation unit, and a detection unit, and a detailed description of the analytical instrument is given in Liu et al. (2016). Briefly, a sample amount of $400 \mathrm{~mL}\left(50 \mathrm{~mL} \mathrm{~min}^{-1} \times 8 \mathrm{~min}\right)$ of the air was pre-concentrated in a stainless steel tube filled with Carbopack ${ }^{\mathrm{TM}} \mathrm{B}$ adsorbent $(60 / 80$ mesh). Once the pre- 
concentration was finished, the adsorption tube was quickly heated to about $100^{\circ}$ and the NMHCs desorbed were injected into a single column (OV-1, $30 \mathrm{~m} \times 0.32 \mathrm{~mm}$ I.D.) for separation. The temperature program of the capillary column used was as follows: $3 \mathrm{~min}$ at $-60^{\circ}$, ramped at $12^{\circ} \mathrm{min}^{-1}$ to $-20^{\circ}$, ramped at $6^{\circ} \mathrm{min}^{-1}$ to $30^{\circ}$, ramped at $10^{\circ} \mathrm{min}^{-1}$ to $170^{\circ}$, then hold for $2 \mathrm{~min}$. The detection unit is a flame ionization detector (FID), and the temperature of the FID is operated at $250^{\circ}$.

We used an external standard method for the quantification of C2-C12 hydrocarbons by diluting 1.0 ppmv standard gas mixtures of 57 NMHCs (provided by Spectra Gases Inc., USA) with high pure nitrogen gas. Five concentrations (1.0$30.0 \mathrm{ppbv}$ ) were used to perform calibrations. $R^{2}$ values for calibration curves were all above 0.99 for NMHCs, indicating that integral areas of peaks were proportional to concentrations of target compounds. We performed weekly calibrations, and the variations in target species responses were within $6 \%$ of the calibration curve. The method detection limits (MDLs) of 0.02-0.10 ppbv for the NMHCs were estimated based on a signal-to-noise ratio of 3 and an enrichment volume of $400 \mathrm{~mL}$ (Liu et al., 2016).

\subsection{PMF model analysis}

The US PMF 5.0 was applied to identify major emission sources of NMHC sources (Sowlat et al., 2016). PMF is a multivariate factor analysis tool that decomposes a matrix of speciated sample data into two matrices-factor contributions and factor profiles that can be interpreted by an analyst as to what sources are represented based on observations at the receptor site (Guo et al., 2010; Ou et al., 2015; Shao et al., 2016; Shi et al., 2009; Xie et al., 2008; Lanz et al., 2007; Zhang et al., 2013). The object function $Q$, based on the uncertainties inherent in each observation, can allow the analyst to review the distribution for each species to evaluate the stability of the solution:

$Q=\sum_{i=1}^{m} \sum_{j=1}^{n}\left[\frac{x_{i j}-\sum_{k=1}^{p} g_{i k} f_{k j}}{u_{i j}}\right]^{2}$,

in which $u_{i j}$ is the uncertainty estimate of source $j$ measured in sample $i, x_{i j}$ is the $j$ th species concentration measured in the $i$ th sample, $g_{i k}$ is the species contribution of the $k$ th source to the $i$ th sample, $f_{k j}$ is the $j$ th species fraction from the $k$ th source, and $p$ is the total number of independent sources.

For the PMF input, it is not necessary to use all of the measured NMHCs for the PMF model due to the fundamental assumption of non-reactivity and/or mass conservation of the PMF model (H. Guo et al., 2011; Ling and Guo, 2014). The selection of the NMHC species for the input of the PMF model was based on the adopted principles in previous studies (Ling and Guo, 2014). In total, 17 major NMHCs, which accounted for about $90 \%$ (ppbv ppbv ${ }^{-1}$ ) of the total concen- trations of the measured NMHC species, were input into the PMF model to explore the sources of observed NMHCs. The uncertainty of input data is another input required by PMF. According to the method recommended by the EPA PMF Fundamentals, the uncertainties for each sample and species (DL) were calculated using the following equation:

uncertainty $=\sqrt{\text { precision }^{2}+\mathrm{DL}^{2}}$,

in which the precision accounts for the relative measurement error determined by calibration of the instruments. Values below the detection limit were replaced by one-half of the DL and their overall uncertainties were set at five-sixths of the DL values. In this analysis, different numbers of factors were tested. The robust mode was used to reduce the influence of extreme values on the PMF solution. In addition, many different starting seeds were tested and no multiple solutions were found. More than $95 \%$ of the residuals were between -3 and 3 for all compounds. The $Q$ values in the robust mode were approximately equal to the degrees of freedom. These features demonstrated that the model simulation results were acceptable.

\section{Results and discussion}

\subsection{The levels and variation characteristics of NMHCs during the sampling period}

There were 53 NMHCs quantified and classified into alkanes, alkenes, aromatics, and acetylene. The variations in total NMHCs (TNMHCs), alkanes, alkenes, aromatics, and acetylene together with meteorological parameters during the measurement period are shown in Fig. 1. It is evident that the variation trends in the NMHC concentrations were basically identical and exhibited significant fluctuation, which was mainly ascribed to the variation in surface wind speed, e.g., the TNMHC concentrations were lower than $30 \mathrm{ppbv}$ when wind speeds were greater than $2 \mathrm{~m} \mathrm{~s}^{-1}$, whereas they sharply increased as the wind speed decreased. Although the surface wind speeds were relatively higher on 25-26 December 2015 than other days with pollution episodes, the concentrations of NMHCs were the highest. The relatively stable and low air temperature during 25-26 December 2015 (Fig. 1d) indicated that the surface wind with the cold air might result in advection inversion, which favored accumulation of the pollutants. The daily average concentration of TNMHCs increased from about 30 ppbv to about $100 \mathrm{ppbv}$ within 3-6 days during the three pollution episodes on 1722 December, 27-29 December, and 31 December-3 January, whereas it increased from about 30 to $165 \mathrm{ppbv}$ within 1 day during the pollution episode on 25-26 December. The strong wind only lasted $5 \mathrm{~h}$ before the severe pollution episode on 25-26 December, whereas the strong wind events lasted at least 1 day before the other pollution episodes. High concentrations of the pollutants after the shorter strong wind 

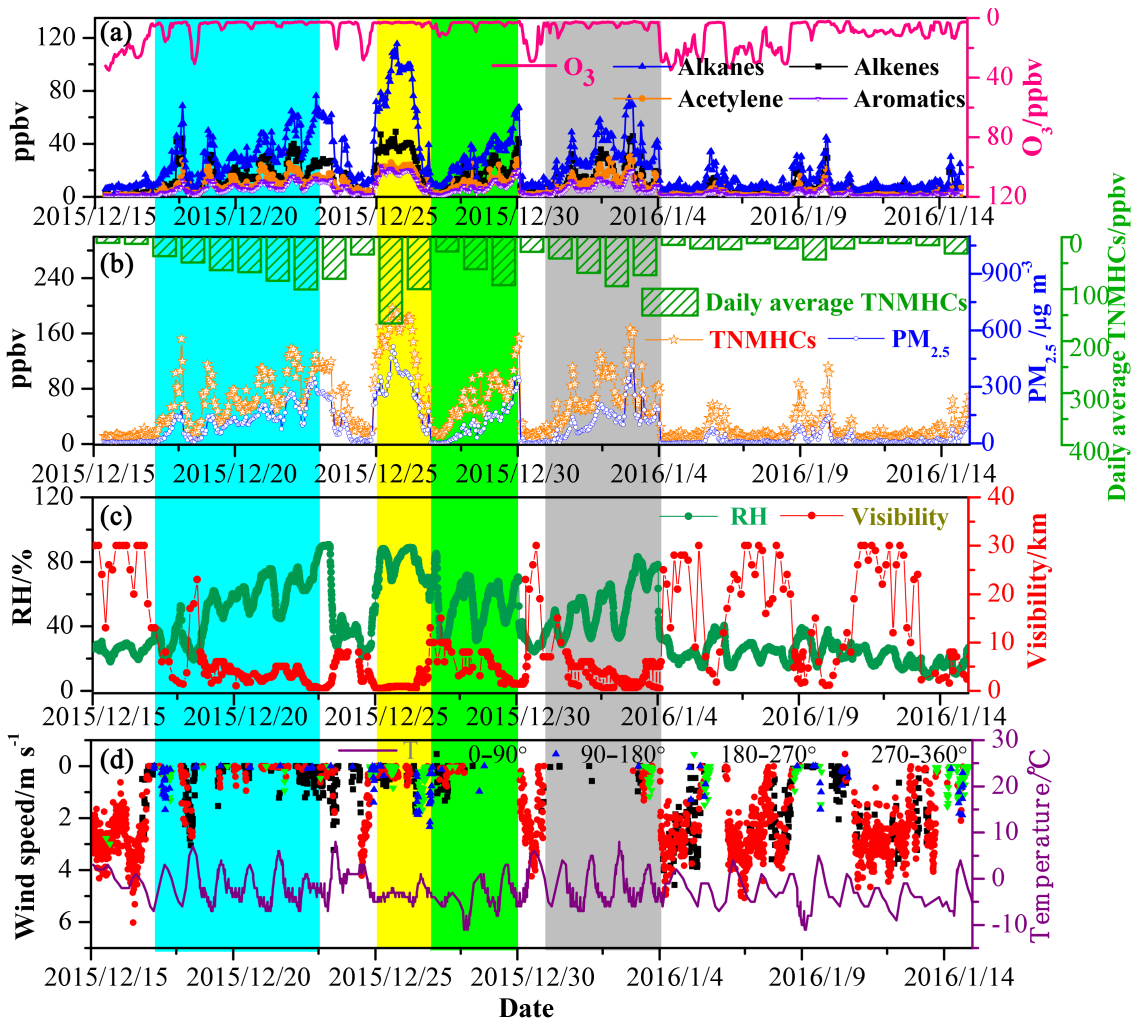

Figure 1. Time series of measured NMHCs, $\mathrm{PM}_{2.5}, \mathrm{O}_{3}$, visibility, relative humidity, temperature, and wind speed. The shaded areas indicate pollution episodes: 17-22 December (cyan), 25-26 December (yellow), 27-29 December (green), and 31 December-3 January (light gray).

event on 24 December were suspected to distribute in the neighboring city of Beijing, which could accelerate the accumulation of the pollutants in Beijing after the strong wind event.

It should be noted that the variation trend in TNMHCs was almost same as that of $\mathrm{PM}_{2.5}$, and a significant linear correlation with coefficient $R^{2}$ of 0.9 was found. In contrast to NMHCs and $\mathrm{PM}_{2.5}$, ozone concentrations approached zero during each haze event and reached the maximum of about 35 ppbv during the daytime just after the haze events followed by strong winds from the northwest (Lin et al., 2011). Although strong winds from the northwest occurred during the period of 12-14 January 2016, ozone concentrations did not evidently increase during the daytime, implying that ozone formation depended on the pollution levels of its precursors (NMHCs and $\mathrm{NO}_{x}$ ). Because NMHCs are solely from direct emissions and $\mathrm{PM}_{2.5}$ is from both direct emissions and secondary formation, the very similar variation trends in them further indicated that meteorological conditions, especially the surface wind speed, played a pivotal role in their accumulation and dispersion. Conversely, some of the NMHCs (e.g., aromatics) measured are the precursors for SOA. The remarkable elevation of the NMHCs during pollution episodes would also make more of a contribution to $\mathrm{PM}_{2.5}$ through SOA formation because of relatively high
$\mathrm{OH}$ radical concentration during the pollution episodes (see Sect. 3.2.2). It should also be mentioned that the odd-even license plate number rule was adopted in Beijing on 1922 December 2015. Compared with the two pollution events on 27-29 December and 31 December-3 January, although the wind speeds were slightly faster, the peak values and the daily average concentrations of TNMHCs and $\mathrm{PM}_{2.5}$ during the period of 17-22 December 2015 were almost the same as the two pollution events without adopting the rule, implying that sources other than vehicle emissions might be dominant for atmospheric NMHCs and $\mathrm{PM}_{2.5}$ during the haze days.

The entire sampling period was divided into three categories based on the daily average visibility values: clear days $(\geq 10 \mathrm{~km}, \mathrm{RH}<90 \%)$, light haze days $(5-10 \mathrm{~km}$, $\mathrm{RH}<90 \%)$, and heavy haze days $(\leq 5 \mathrm{~km}, \mathrm{RH}<90 \%)$ (Yang et al., 2012; Lin et al., 2014). As shown in Table 1, there were 11 heavy haze days, 8 light haze days, and 12 clear days during the 31 sampling days (nonprecipitation days). The mean concentrations and standard deviations of TNMHCs, alkanes, alkenes, aromatics, and acetylene during the three categories are presented in Table 2. It is evident that the average concentrations of alkanes, alkenes, aromatics, acetylene, and TNMHCs remarkably increased from clear days to heavy haze days, and their average concentrations during heavy haze days were at least a factor of 5 higher 
Table 1. Classification of pollution status and the corresponding meteorological conditions as well as the date.

\begin{tabular}{|c|c|c|c|c|c|}
\hline $\begin{array}{l}\text { Pollution } \\
\text { status }\end{array}$ & $\begin{array}{r}\text { Visibility } \\
(\mathrm{km})\end{array}$ & $T\left({ }^{\circ} \mathrm{C}\right)$ & $\mathrm{RH}(\%)$ & $\begin{array}{l}\text { Wind speed } \\
\qquad\left(\mathrm{m} \mathrm{s}^{-1}\right)\end{array}$ & Date \\
\hline Heavy haze days & $1.41 \pm 1.76$ & $\begin{array}{r}0.83 \pm 2.86^{\mathrm{a}} \\
-0.66 \pm 1.90^{\mathrm{b}}\end{array}$ & $\begin{array}{l}59.17 \pm 16.19^{\mathrm{a}} \\
65.94 \pm 13.09^{\mathrm{b}}\end{array}$ & $\begin{array}{l}0.19 \pm 0.35^{\mathrm{a}} \\
0.07 \pm 0.16^{\mathrm{b}}\end{array}$ & $\begin{array}{l}\text { 19-23 Dec 2015, 25-26 Dec 2015, } \\
29 \text { Dec 2015, 1-3 Jan } 2016\end{array}$ \\
\hline Light haze days & $6.81 \pm 5.37$ & $\begin{array}{l}-0.72 \pm 4.04^{\mathrm{a}} \\
-1.19 \pm 3.28^{\mathrm{b}}\end{array}$ & $\begin{array}{l}24.39 \pm 11.28^{\mathrm{a}} \\
31.92 \pm 14.58^{\mathrm{b}}\end{array}$ & $\begin{array}{l}0.37 \pm 0.68^{\mathrm{a}} \\
0.07 \pm 0.23^{\mathrm{b}}\end{array}$ & $\begin{array}{l}\text { 17-18 Dec 2015, } 24 \operatorname{Dec} 2015 \text {, } \\
\text { 27-28 Dec 2015, } 31 \text { Dec 2015, } \\
\text { 9 Jan 2016, } 14 \text { Jan } 2016\end{array}$ \\
\hline Clear days & $19.96 \pm 9.7$ & $\begin{array}{l}1.63 \pm 2.18^{\mathrm{a}} \\
0.20 \pm 2.11^{\mathrm{b}}\end{array}$ & $\begin{array}{l}20.35 \pm 6.01^{\mathrm{a}} \\
26.26 \pm 7.56^{\mathrm{b}}\end{array}$ & $\begin{array}{l}2.02 \pm 1.29^{\mathrm{a}} \\
1.78 \pm 1.51^{\mathrm{b}}\end{array}$ & $\begin{array}{l}\text { 15-16 Dec 2015, } 30 \text { Dec } 2015, \\
\text { 4-8 Jan 2016, 10-13 Jan } 2016\end{array}$ \\
\hline
\end{tabular}

${ }^{\mathrm{a}}$ Daytime. ${ }^{\mathrm{b}}$ Nighttime.

than those during clear days, which were in good agreement with the previous studies (Y. J. Zhang et al., 2014). Alkanes accounted for the largest proportions (49.8-55.8\%), followed by alkenes (21.5-24.7\%), acetylene (13.5-15.9\%), and aromatics (9.3-10.7\%). The proportion order of alkenes, acetylene, and aromatics obtained by this study in winter was different from that reported by previous studies in summer (Wang et al., 2010; Li et al., 2016), which was probably due to the different sources (e.g., additional domestic coal combustion in winter) for atmospheric NMHCs in Beijing between the two seasons. The 10 most prevalent NMHCs measured in this study are presented in Table 3 for comparison with those from the cities in China. The average concentrations of the 10 most prevalent NMHCs observed in this study were basically within the values reported in various Chinese cities (Barletta et al., 2005; Song et al., 2012; An et al., 2014; Li et al., 2015; Zou et al., 2015; Jia et al., 2016). During haze days, the average concentrations of the NMHCs in winter in Beijing were less than those reported in Foshan (S. Guo et al., 2011), whereas they were remarkably greater than those reported in summer in Beijing (Guo et al., 2012). With only the exception of isobutane and isopentane, the average concentrations of the other eight NMHCs during both the whole measurement period and haze days in this study were evidently greater than those reported in summer in Beijing. The relatively higher NMHCs measured in this study during the wintertime were suspected to be due to the different meteorological conditions and different sources between the two seasons.

\subsection{Diurnal variations in NMHCs and the propane / propene ratios}

\subsubsection{Diurnal variations in NMHCs}

Diurnal variations in alkanes, alkenes, aromatics, and acetylene under different visibility levels are presented in Fig. 2. The two obvious peaks for the NMHCs in the morning and evening rush hours on clear days (Fig. 2a) indicated that the exhaust of vehicles was an important source for atmo- spheric NMHCs in Beijing. For light haze days (Fig. 2b), only small peak in NMHCs could be observed during morning rush hours, and the concentration of NMHCs steadily increased from 18:00 to 01:00 (UTC/GMT + 8) of the next day. For heavy haze days (Fig. 2c), the peak levels of NMHCs during the two rush hours disappeared, and the concentration of NMHCs steadily increased from 17:00 to 20:00 (UTC/GMT + 8) and began to level off until 07:00 of the next day. The three distinct diurnal variations in NMHCs under the three typical days were suspected to relate to the diurnal variations in the boundary layer. In addition to the highest planetary boundary layer height during clear days (Zheng et al., 2015; Lin et al., 2011; H. Zhang et al., 2014), the highest wind speed during both nighttime and daytime on clear days also favored diffusion of pollutants, resulting in the lowest levels of atmospheric NMHCs on clear days. Both the relatively high boundary layer (Gao et al., 2015; Quan et al., 2013; Liu et al., 2013) and wind speeds could result in the lowest levels of the pollutants during nighttime, which were suspected to make the peak levels of atmospheric NMHCs more evident during daytime rush hours.

\subsubsection{Diurnal variations in propane / propene ratios}

Considering the large difference in the reactivity between propane and propene towards $\mathrm{NO}_{3}$ and $\mathrm{OH}$ radicals, the diurnal variations in propane / propene ratios were analyzed to reveal the nighttime and daytime reaction processes. Diurnal variations in propane / propene ratios on clear days, light haze days, and heavy haze days are shown in Fig. 3. Two evident peaks in the propane/propene ratios appeared in the early morning (about 05:00) before sun rise and at noontime (about 12:00) on clear days, whereas only one peak occurred around 15:00 during the haze days. Distinct peaks in the propane / propene ratios were mainly ascribed to the different reactivity of propane and propene because of their possible common sources indicated by the significant correlation $\left(R^{2}=0.8\right)$ between propane and propene during the measurement period. The atmospheric reactions of propane and propene include 
Table 2. The method detection limit (MDL), mean concentrations, and standard deviations of NMHCs during clear days, light haze days, and heavy haze days (ppbv).

\begin{tabular}{|c|c|c|c|c|}
\hline Compound & Clear days & Light haze days & Heavy haze days & MDL \\
\hline Ethylene* & $2.43 \pm 3.32$ & $6.54 \pm 5.02$ & $15.14 \pm 7.01$ & 0.08 \\
\hline Propene* & $0.89 \pm 1.52$ & $2.35 \pm 2.31$ & $4.51 \pm 2.42$ & 0.09 \\
\hline 1-Butene & $0.19 \pm 0.19$ & $0.44 \pm 0.29$ & $0.78 \pm 0.38$ & 0.05 \\
\hline Trans-2-butene & $0.11 \pm 0.03$ & $0.12 \pm 0.04$ & $0.15 \pm 0.08$ & 0.05 \\
\hline Cis-2-butene & $0.12 \pm 0.02$ & $0.12 \pm 0.05$ & $0.17 \pm 0.07$ & 0.05 \\
\hline 1-Penene & $0.07 \pm 0.04$ & $0.11 \pm 0.05$ & $0.19 \pm 0.09$ & 0.05 \\
\hline Isoprene & $0.07 \pm 0.04$ & $0.12 \pm 0.05$ & $0.16 \pm 0.05$ & 0.05 \\
\hline Trans-2-pentene & $0.06 \pm 0.02$ & $0.07 \pm 0.03$ & $0.09 \pm 0.04$ & 0.05 \\
\hline Cis-2-pentene & $0.16 \pm 0.23$ & $0.22 \pm 0.21$ & $0.51 \pm 0.34$ & 0.05 \\
\hline 1-Hexene & $0.11 \pm 0.01$ & $0.11 \pm 0.02$ & $0.14 \pm 0.05$ & 0.03 \\
\hline Ethane* & $3.71 \pm 2.79$ & $8.03 \pm 4.66$ & $17.63 \pm 8.48$ & 0.09 \\
\hline Propane* & $2.12 \pm 2.02$ & $5.18 \pm 3.37$ & $12.52 \pm 6.01$ & 0.08 \\
\hline n-Butane* & $0.73 \pm 0.81$ & $1.76 \pm 1.26$ & $3.71 \pm 2.14$ & 0.06 \\
\hline n-Pentane* & $0.26 \pm 0.22$ & $0.54 \pm 0.31$ & $1.31 \pm 0.78$ & 0.05 \\
\hline n-Hexane* & $0.93 \pm 0.79$ & $0.81 \pm 0.86$ & $1.04 \pm 0.69$ & 0.03 \\
\hline n-Heptane* & $0.07 \pm 0.06$ & $0.15 \pm 0.08$ & $0.35 \pm 0.18$ & 0.03 \\
\hline n-Octane & $0.03 \pm 0.02$ & $0.05 \pm 0.03$ & $0.09 \pm 0.05$ & 0.02 \\
\hline Nonane & $0.03 \pm 0.02$ & $0.05 \pm 0.03$ & $0.09 \pm 0.04$ & 0.02 \\
\hline n-Decane & $0.02 \pm 0.01$ & $0.03 \pm 0.02$ & $0.06 \pm 0.03$ & 0.02 \\
\hline n-Undecane & $0.03 \pm 0.02$ & $0.03 \pm 0.01$ & $0.04 \pm 0.01$ & 0.03 \\
\hline Dodecane & $0.05 \pm 0.04$ & $0.05 \pm 0.03$ & $0.05 \pm 0.03$ & 0.09 \\
\hline Isobutane* & $0.44 \pm 0.41$ & $0.91 \pm 0.59$ & $2.05 \pm 1.04$ & 0.07 \\
\hline Isopentane* & $0.39 \pm 0.38$ & $0.83 \pm 0.51$ & $1.76 \pm 0.88$ & 0.05 \\
\hline 2,2-Dimethylbutane & $0.06 \pm 0.04$ & $0.08 \pm 0.07$ & $0.13 \pm 0.1$ & 0.04 \\
\hline Cyclopentane & $0.07 \pm 0.05$ & $0.16 \pm 0.08$ & $0.29 \pm 0.13$ & 0.05 \\
\hline 2,3-Dimethylbutane & $0.03 \pm 0.03$ & $0.07 \pm 0.05$ & $0.09 \pm 0.05$ & 0.04 \\
\hline 2-Methylpentane* & $0.16 \pm 0.14$ & $0.36 \pm 0.26$ & $0.59 \pm 0.33$ & 0.04 \\
\hline 3-Methylpentane & $0.18 \pm 0.13$ & $0.24 \pm 0.18$ & $0.42 \pm 0.26$ & 0.03 \\
\hline Methylcyclopentane & $0.21 \pm 0.15$ & $0.32 \pm 0.24$ & $0.65 \pm 0.38$ & 0.03 \\
\hline 2,4-Dimethylpentane & $0.03 \pm 0.01$ & $0.04 \pm 0.01$ & $0.05 \pm 0.02$ & 0.03 \\
\hline Cyclohexane & $0.07 \pm 0.05$ & $0.13 \pm 0.13$ & $0.24 \pm 0.13$ & 0.03 \\
\hline 2-Methylhexane & $0.05 \pm 0.03$ & $0.09 \pm 0.05$ & $0.18 \pm 0.08$ & 0.03 \\
\hline 3-Methylhexane & $0.07 \pm 0.08$ & $0.14 \pm 0.09$ & $0.36 \pm 0.21$ & 0.03 \\
\hline 2,2,4-Trimethylpentane & $0.06 \pm 0.05$ & $0.14 \pm 0.07$ & $0.22 \pm 0.09$ & 0.02 \\
\hline Methylcyclohexane & $0.05 \pm 0.04$ & $0.11 \pm 0.07$ & $0.26 \pm 0.14$ & 0.03 \\
\hline 2,3,4-Trimethylpentane & $0.02 \pm 0.02$ & $0.05 \pm 0.03$ & $0.07 \pm 0.03$ & 0.03 \\
\hline 2-Methylheptane & $0.03 \pm 0.01$ & $0.05 \pm 0.03$ & $0.08 \pm 0.03$ & 0.02 \\
\hline 3-Methylheptane & $0.02 \pm 0.01$ & $0.03 \pm 0.02$ & $0.05 \pm 0.02$ & 0.02 \\
\hline Benzene* & $0.59 \pm 0.72$ & $1.33 \pm 0.96$ & $3.54 \pm 1.76$ & 0.03 \\
\hline Toluene* & $0.55 \pm 0.66$ & $1.34 \pm 0.83$ & $3.18 \pm 1.72$ & 0.03 \\
\hline Ethylbenzene* & $0.10 \pm 0.14$ & $0.27 \pm 0.18$ & $0.68 \pm 0.34$ & 0.02 \\
\hline m,p-Xylene* & $0.24 \pm 0.35$ & $0.66 \pm 0.45$ & $1.56 \pm 0.81$ & 0.02 \\
\hline Styrene & $0.06 \pm 0.06$ & $0.13 \pm 0.09$ & $0.25 \pm 0.14$ & 0.03 \\
\hline o-Xylene* & $0.09 \pm 0.12$ & $0.24 \pm 0.16$ & $0.57 \pm 0.29$ & 0.03 \\
\hline Isopropylbenzene & $0.01 \pm 0.01$ & $0.02 \pm 0.01$ & $0.02 \pm 0.01$ & 0.02 \\
\hline n-Propylbenzene & $0.02 \pm 0.01$ & $0.02 \pm 0.01$ & $0.04 \pm 0.02$ & 0.03 \\
\hline m-Ethyltoluene & $0.04 \pm 0.03$ & $0.08 \pm 0.04$ & $0.14 \pm 0.06$ & 0.02 \\
\hline 1,3,5-Thrimethylbenzene & $0.02 \pm 0.01$ & $0.04 \pm 0.02$ & $0.06 \pm 0.02$ & 0.03 \\
\hline o-Ethyltoluene & $0.02 \pm 0.01$ & $0.03 \pm 0.02$ & $0.06 \pm 0.03$ & 0.03 \\
\hline 1,2,4-Thrimethylbenzene & $0.04 \pm 0.04$ & $0.11 \pm 0.06$ & $0.19 \pm 0.09$ & 0.03 \\
\hline 1,2,3-Thrimethylbenzene & $0.02 \pm 0.01$ & $0.03 \pm 0.02$ & $0.06 \pm 0.04$ & 0.03 \\
\hline m-Diethylbenzene & $0.02 \pm 0.01$ & $0.03 \pm 0.01$ & $0.03 \pm 0.01$ & 0.03 \\
\hline p-Diethylbenzene & $0.02 \pm 0.02$ & $0.02 \pm 0.01$ & $0.03 \pm 0.01$ & 0.03 \\
\hline Acetylene* & $2.51 \pm 2.86$ & $6.72 \pm 4.71$ & $13.69 \pm 6.09$ & 0.10 \\
\hline Alkenes & $3.67 \pm 1.78$ & $10.01 \pm 3.21$ & $21.84 \pm 6.12$ & \\
\hline Alkanes & $9.52 \pm 2.61$ & $20.17 \pm 4.90$ & $44.83 \pm 16.33$ & \\
\hline Aromatics & $1.58 \pm 0.67$ & $3.84 \pm 1.08$ & $9.63 \pm 3.28$ & \\
\hline TNMHCs & $17.05 \pm 5.87$ & $40.46 \pm 10.92$ & $89.98 \pm 28.40$ & \\
\hline
\end{tabular}

* The compounds selected for PMF analysis. 
Table 3. Comparisons of the 10 most prevalent NMHCs in Beijing with other cities in China (ppbv).

\begin{tabular}{|c|c|c|c|c|c|c|c|c|c|c|c|}
\hline & \multicolumn{3}{|c|}{ This study } & \multirow[t]{2}{*}{43 cities } & \multirow[t]{2}{*}{ NJ } & \multirow[t]{2}{*}{ GZ } & \multirow[t]{2}{*}{$\mathrm{SH}$} & \multirow[t]{2}{*}{$\mathrm{FS}^{*}$} & \multirow[t]{2}{*}{$\mathrm{LZ}$} & \multirow[t]{2}{*}{$\mathrm{BJ}$} & \multirow[t]{2}{*}{$\mathrm{BJ}^{*}$} \\
\hline & The range & AVG & Haze & & & & & & & & \\
\hline Ethane & $1.89-44.34$ & 9.68 & 13.46 & $3.7-17.0$ & 6.90 & 3.66 & - & 18.52 & - & 4.37 & 2.26 \\
\hline Ethylene & $0.12-31.65$ & 7.91 & 11.37 & $2.1-34.8$ & 5.70 & 2.99 & - & 20.58 & - & 2.33 & 6.63 \\
\hline Acetylene & $0.40-30.86$ & 7.50 & 10.60 & $2.9-58.3$ & 3.12 & - & - & 23.38 & - & 2.17 & 5.47 \\
\hline Propane & $0.86-28.51$ & 6.57 & 9.43 & $1.5-20.8$ & 3.30 & 4.34 & 5.16 & 12.98 & 3.40 & 2.44 & 5.45 \\
\hline Propene & $0.14-24.10$ & 2.55 & 3.54 & $0.2-8.2$ & 2.50 & 1.32 & 1.70 & 6.84 & 2.43 & - & 3.32 \\
\hline n-Butane & $0.09-14.27$ & 2.10 & 2.86 & $0.6-18.8$ & 1.70 & 3.07 & 1.69 & 3.76 & 1.75 & 1.43 & 3.49 \\
\hline Benzene & $0.07-8.27$ & 1.81 & 2.59 & $0.7-10.4$ & 3.10 & 0.62 & 2.00 & 4.05 & 1.94 & 0.82 & 2.54 \\
\hline Toluene & $0.12-8.41$ & 1.67 & 2.38 & $0.4-11.2$ & 2.10 & 4.59 & 4.86 & 10.98 & 1.01 & 1.33 & 2.97 \\
\hline Isobutane & $0.10-5.03$ & 1.13 & 1.55 & $0.4-4.6$ & 1.51 & 2.67 & 1.20 & 3.02 & 2.43 & 1.03 & 2.50 \\
\hline Isopentane & $0.08-6.03$ & 1.00 & 1.36 & $0.3-18.8$ & 1.12 & 1.72 & 1.63 & 13.07 & 2.43 & 0.99 & 4.06 \\
\hline
\end{tabular}

The 43 cities in China from January to February 2001 (Barletta et al., 2005): NJ, Nanjing, March 2011-February 2012 (An et al., 2014); GZ, Guangzhou, June 2011-May 2012 (Zou et al., 2015); SH, Shanghai, December 2006-February 2007 (Song et al., 2012); FS, Foshan, December 2008 (S. Guo et al., 2011); LZ, Lanzhou, June 2013-August 2013 (Jia et al., 2016); BJ, Beijing, May 2014 (Li et al., 2015); BJ, Beijing, August 2006 (Guo et al., 2012). * Haze days.

propane $+\mathrm{OH} \stackrel{k_{1}}{\longrightarrow}$ products

$$
k_{1}=1.09 \times 10^{-12} \mathrm{~cm}^{3} \text { molecule } \mathrm{e}^{-1} \mathrm{~s}^{-1}
$$

(Atkinson, 2003)

propene $+\mathrm{OH} \stackrel{k_{2}}{\longrightarrow}$ products

$$
k_{2}=2.57 \times 10^{-11} \mathrm{~cm}^{3} \text { molecule }{ }^{-1} \mathrm{~s}^{-1}
$$

(Daranlot et al., 2010)

propene $+\mathrm{O}_{3} \stackrel{k_{3}}{\longrightarrow}$ products

$$
k_{3}=1.06 \times 10^{-17} \mathrm{~cm}^{3} \text { molecule } \mathrm{s}^{-1} \mathrm{~s}^{-1}
$$

(Wegener et al., 2007)

propane $+\mathrm{NO}_{3} \stackrel{k_{4}}{\longrightarrow}$ products

$$
k_{4}=7.00 \times 10^{-17} \mathrm{~cm}^{3} \text { molecule }{ }^{-1} \mathrm{~s}^{-1}
$$

(Atkinson et al., 2001)

propene $+\mathrm{NO}_{3} \stackrel{k_{5}}{\longrightarrow}$ products

$$
k_{5}=9.54 \times 10^{-15} \mathrm{~cm}^{3} \text { molecule }{ }^{-1} \mathrm{~s}^{-1}
$$

(Atkinson et al., 2001)

$$
\begin{aligned}
& \mathrm{O}_{3}+\mathrm{NO}_{2} \stackrel{k_{6}}{\longrightarrow} \mathrm{NO}_{3}+\mathrm{O}_{2} \\
& k_{6}=3.52 \times 10^{-17} \mathrm{~cm}^{3} \text { molecule }{ }^{-1} \mathrm{~s}^{-1}
\end{aligned}
$$

(Atkinson et al., 2004).

The rate constants for the reactions of $\mathrm{OH}$ and $\mathrm{NO}_{3}$ with propene are a factor of 2.4 and 136.3 greater than with propane, respectively. In addition, $\mathrm{O}_{3}$ can react with propene but not with propane. The evident $\mathrm{O}_{3}$ concentrations (about $25 \mathrm{ppbv}$ ) during nighttime on clear days could react with $\mathrm{NO}_{2}$ to form $\mathrm{NO}_{3}$ radicals via reaction (8), whereas the formation of $\mathrm{NO}_{3}$ radicals was completely blocked during haze days because $\mathrm{O}_{3}$ concentrations were extremely low (nearly zero). Therefore, the peak in the propane / propene ratios that appeared at nighttime during clear days was rationally ascribed to the additional consumption of propene by $\mathrm{O}_{3}$ and $\mathrm{NO}_{3}$. Based on the data measured, the $\mathrm{OH}$ and $\mathrm{NO}_{3}$ concentrations were roughly estimated according to the following chemical kinetic equations. The Eqs. 9-12 were used to estimate the concentrations of $\mathrm{OH}$ during the daytime and Eqs. (13)-(16) were used to estimate the concentrations of $\mathrm{NO}_{3}$ during nighttime:

$$
\begin{aligned}
& {[\text { propane }]_{0}=[\text { propane }]_{t} \times e^{k_{1}[\mathrm{OH}] \Delta t}} \\
& {[\text { propene }]_{0}=[\text { propene }]_{t} \times e^{\left(k_{2}[\mathrm{OH}]+k_{3}\left[\mathrm{O}_{3}\right]\right) \Delta t}}
\end{aligned}
$$

$$
\begin{gathered}
\ln \frac{[\text { propane }]_{t}}{[\text { propene }]_{t}}=\left\{\left(k_{2}-k_{1}\right)[\mathrm{OH}]+k_{3}\left[\mathrm{O}_{3}\right]\right\} \Delta t \\
+\ln \frac{[\text { propane }]_{0}}{[\text { propene }]_{0}}
\end{gathered}
$$

$$
[\mathrm{OH}]=\frac{1}{k_{2}-k_{1}} \times\left\{\left(\ln \frac{[\text { propane }]_{t}}{[\text { propene }]_{t}}-\ln \frac{[\text { propane }]_{0}}{[\text { propene }]_{0}}\right) /\right.
$$

$$
\left.\Delta t-k_{3}\left[\mathrm{O}_{3}\right]\right\}
$$

$[\text { propane }]_{0}=[\text { propane }]_{t} \times e^{\left(k_{4}\left[\mathrm{NO}_{3}\right]\right) \Delta t}$

$[\text { propene }]_{0}=[\text { propene }]_{t} \times e^{\left(k_{5}\left[\mathrm{NO}_{3}\right]+k_{3}\left[\mathrm{O}_{3}\right]\right) \Delta t}$

$\ln \frac{[\text { propane }]_{t}}{[\text { propene }]_{t}}=\left\{\left(k_{5}-k_{4}\right)\left[\mathrm{NO}_{3}\right]+k_{3}\left[\mathrm{O}_{3}\right]\right\} \Delta t$

$$
+\ln \frac{[\text { propane }]_{0}}{[\text { propene }]_{0}}
$$



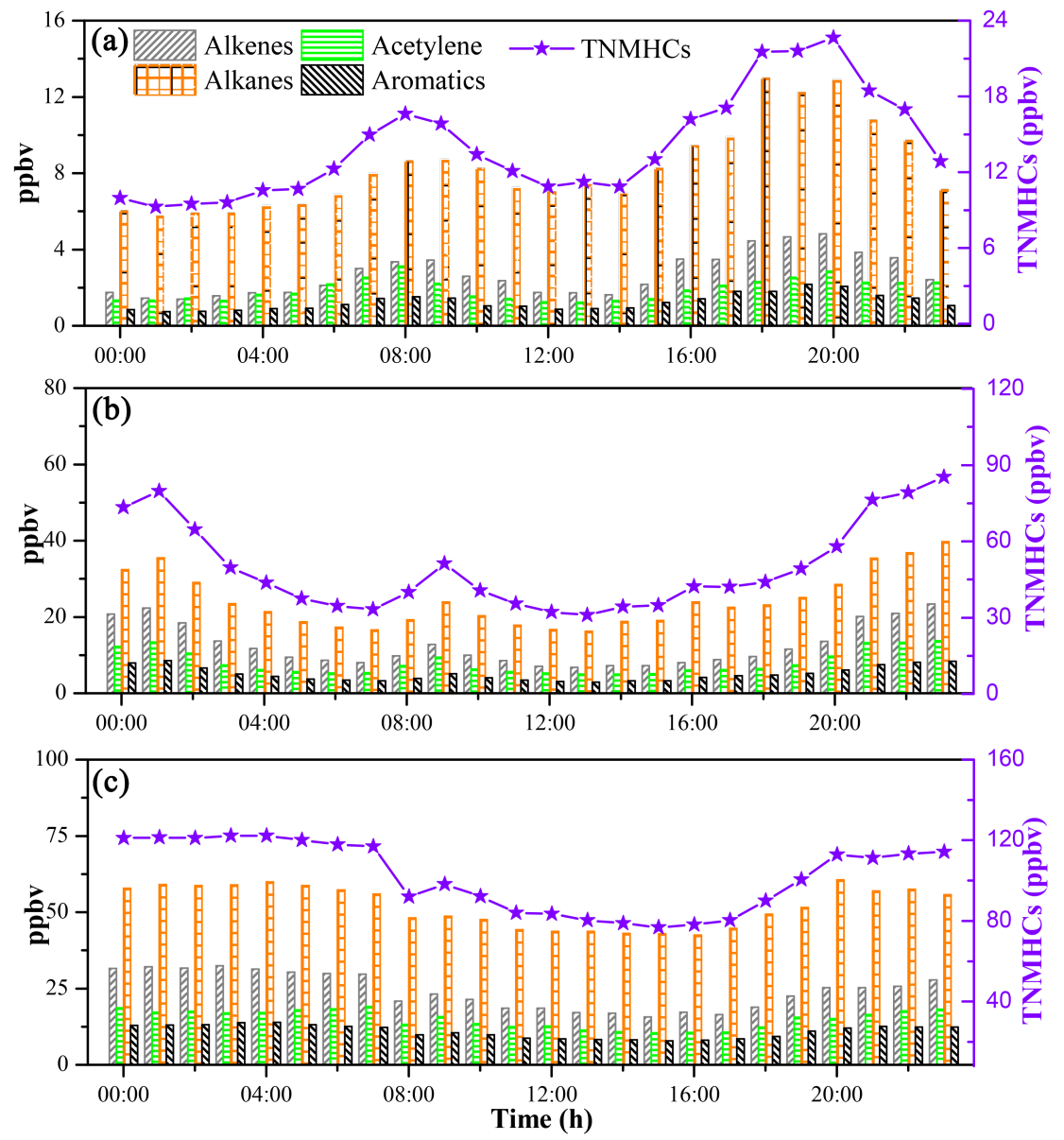

Figure 2. Diurnal variations in alkanes, acetylene, alkenes, aromatics, and TNMHC during (a) clear days, (b) light haze days, and (c) heavy haze days.

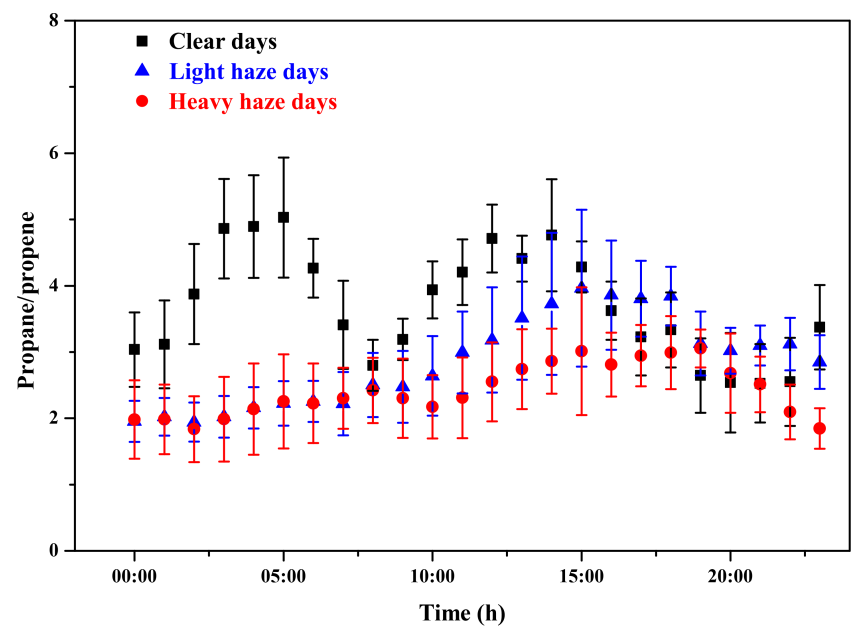

Figure 3. Diurnal variations in propane / propene ratios during clear days, light haze days, and heavy haze days.

$$
\begin{gathered}
{\left[\mathrm{NO}_{3}\right]=\frac{1}{k_{5}-k_{4}} \times\left\{\left(\ln \frac{[\text { propane }]_{t}}{[\text { propene }]_{t}}-\ln \frac{[\text { propane }]_{0}}{[\text { propene }]_{0}}\right) /\right.} \\
\left.\Delta t-k_{3}\left[\mathrm{O}_{3}\right]\right\} .
\end{gathered}
$$

Here, $[\mathrm{OH}]$ is the average $\mathrm{OH}$ radical concentration (molecules cm ${ }^{-3}$ ), $\left[\mathrm{NO}_{3}\right]$ is the average $\mathrm{NO}_{3}$ radical concentration (molecules $\mathrm{cm}^{-3}$ ), $\left[\mathrm{O}_{3}\right]$ is the average ozone concentration (molecules $\mathrm{cm}^{-3}$ ), $\Delta t$ is the exposure time (s) of $\mathrm{OH}$ or $\mathrm{NO}_{3}$, [propane $]_{0}$ and $[\text { propene }]_{0}$ are their initial concentrations when the propane / propene ratio begins to increase, and $[\text { propane }]_{t}$ and $[\text { propene }]_{t}$ are their concentrations at $t$ (s) during the period of increasing propane / propene ratios.

Good linear correlations $\left(R^{2} \geq 0.9\right)$ between $\ln \frac{\text { [propane }]_{t}}{\text { [propene }_{t}}$ and $t$ were found during the period from 09:00 to 14:00 for most days and during the period of about 00:00-05:00 for most clear days, indicating that the concentration variations in propane and propene basically abided by the chemical kinetic rules above. The $\mathrm{OH}$ concentrations were calcu- 

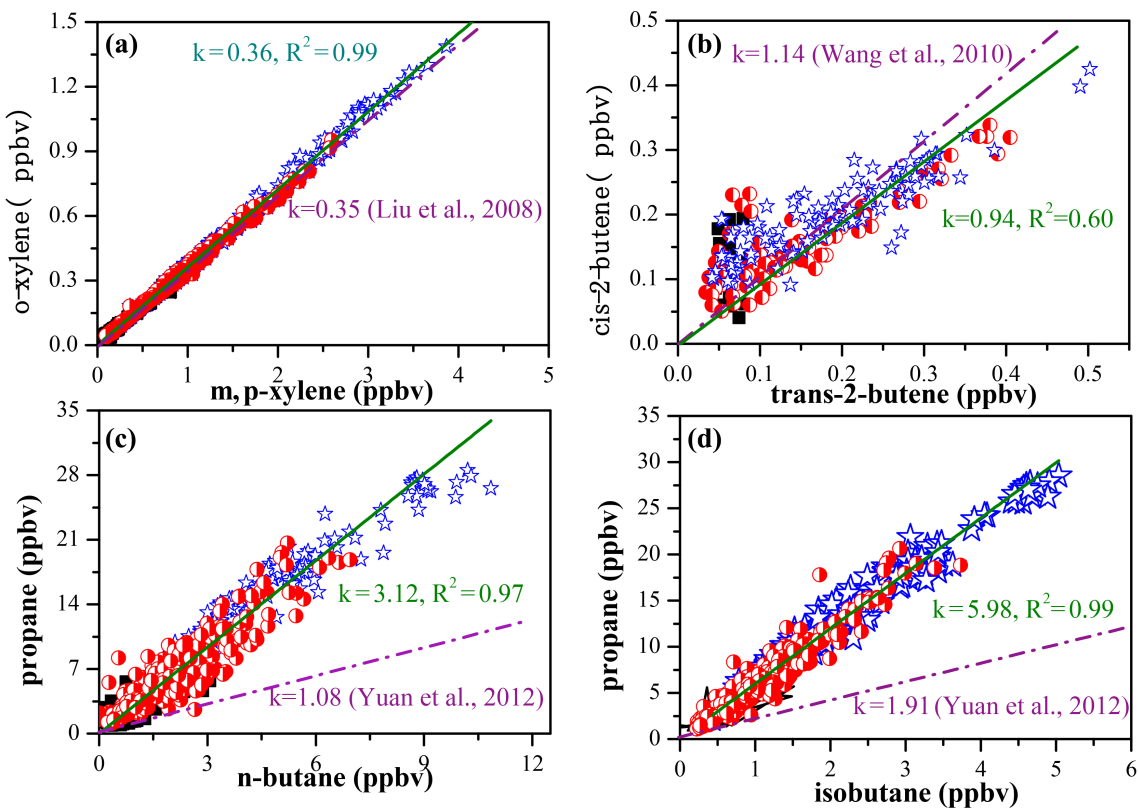

Figure 4. Ratios and linear correlation coefficients $\left(R^{2}\right)$ between (a) o-xylene and m,p-xylene, (b) cis-2-butene and trans-2-butene, (c) propane and n-butane, and (d) propane and isobutane during clear days (in black), light haze days (in red), and heavy haze days (in blue).

Table 4. Emission ratios of NMHC pairs in Beijing and other regions and comparisons with vehicle emissions.

\begin{tabular}{|c|c|c|c|c|c|c|c|c|c|c|c|c|}
\hline & $\begin{array}{l}\text { This } \\
\text { study }\end{array}$ & \multicolumn{2}{|c|}{$\begin{array}{l}43 \text { Chinese } \\
\text { cities }\end{array}$} & $\begin{array}{r}\text { Vehicle } \\
\text { emissions }\end{array}$ & \multicolumn{2}{|c|}{ Beijing } & \multicolumn{2}{|c|}{$\begin{array}{c}\text { Pearl River } \\
\text { Delta }\end{array}$} & \multirow{2}{*}{$\begin{array}{l}\text { Houston } \\
\text { Ratio }^{\mathrm{e}}\end{array}$} & \multirow{2}{*}{$\begin{array}{r}\text { Mexico } \\
\text { City } \\
\text { Ratio }\end{array}$} & \multirow{2}{*}{$\begin{array}{r}\text { Northeastern } \\
\text { US } \\
\text { Ratio }\end{array}$} & \multirow{2}{*}{$\begin{array}{l}\text { Tokyo } \\
\text { Ratio }\end{array}$} \\
\hline & Slope $\left(R^{2}\right)$ & Slo & & Ratio & Slope ${ }^{b}$ & Ratio $^{b}$ & Slope ${ }^{c}$ & Ratio $^{\mathrm{d}}$ & & & & \\
\hline Benzene / toluene & $1.06(0.96)$ & $\begin{array}{r}> \\
1.18\end{array}$ & $\begin{array}{r}\sim \\
0.70\end{array}$ & & & $\begin{array}{r}0.43 / 1.52^{\mathrm{f}} \\
0.38 / 0.88\end{array}$ & & 0.36 & & & & \\
\hline Benzene / acetylene & $0.22(0.81)$ & 0.26 & 0.13 & $0.62^{\mathrm{b}}$ & $0.25 / 0.27$ & $0.27 / 0.34$ & 0.48 & 0.48 & & $0.3^{\mathrm{g}}$ & $0.17 / 0.30^{\mathrm{g}}$ & $0.29^{\mathrm{g}}$ \\
\hline Ethylene / acetylene & $1.08(0.91)$ & 1.01 & 0.76 & & & $0.66 / 1.00$ & & 0.80 & & & & \\
\hline Benzene / ethylbenzene & $4.90(0.91)$ & 4.91 & 2.04 & & & $0.93 / 2.4$ & & 1.90 & & & & \\
\hline Toluene / ethylene & $0.20(0.88)$ & & 0.31 & $0.76^{\mathrm{b}}$ & $0.63 / 0.68$ & $0.61 / 1.26$ & 0.46 & 1.67 & & $0.67^{\mathrm{g}}$ & $0.48 / 0.83^{g}$ & $1.11^{\mathrm{g}}$ \\
\hline Benzene / ethylene & $0.23(0.96)$ & & 0.17 & & & $0.29 / 0.47$ & & 0.61 & & & & \\
\hline Toluene / acetylene & $0.22(0.81)$ & & 0.24 & & & $0.43 / 0.83$ & & 0.26 & & & & \\
\hline Ethylbenzene / toluene & $0.21(0.97)$ & & & $0.24^{\mathrm{h}}$ & & $0.31 / 0.37$ & 0.20 & 0.19 & 0.14 & $0.12^{\mathrm{i}}$ & & \\
\hline o-Xylene / m,p-xylene & $0.36(0.99)$ & & & $0.35^{\mathrm{h}}$ & & $0.28 / 0.60$ & 0.41 & 0.58 & 0.37 & $0.4^{\mathrm{i}}$ & & \\
\hline Propane / toluene & $3.91(0.92)$ & & & $0.08 / 0.98^{h}$ & & $1.13 / 3.18$ & 0.32 & 0.69 & & & & \\
\hline Propane / acetylene & $0.93(0.82)$ & & & $0.06 / 1.80^{\mathrm{h}}$ & & $0.65 / 1.51$ & 0.42 & 0.92 & & & $2.19^{j}$ & $2.90^{\mathrm{k}}$ \\
\hline Propane / isobutane & $5.98(0.95)$ & & & $0.74 / 3.85^{\mathrm{h}}$ & & $1.65 / 1.94$ & 1.91 & 2.00 & & & & \\
\hline Propane / n-butane & $3.12(0.94)$ & & & $0.49 / 1.91^{\mathrm{h}}$ & & $1.52 / 1.97$ & 1.08 & 1.63 & & & & \\
\hline Propane / isopentane & $6.91(0.85)$ & & & $0.09 / 0.58^{\mathrm{h}}$ & & $1.29 / 1.61$ & 1.49 & 2.25 & & & & \\
\hline Trans-2-butene / cis-2-butene & $1.06(0.60)$ & & & $1.14^{\mathrm{b}}$ & $1.13 / 1.23$ & $1 / 1.6$ & 1.11 & & 0.88 & $1.28^{i}$ & & \\
\hline
\end{tabular}

${ }^{a}$ Results from 43 Chinese cities in 2001 (Barletta et al., 2005). ${ }^{b}$ Results from Beijing in summer of 2008 (Wang et al., 2010). ${ }^{\mathrm{c}}$ Results from Guangzhou in 2006 and 2008 (Yuan et al., 2012 ). ${ }^{\mathrm{d}}$ Results from the Pearl River Delt in 2008-2009 (Louie et al., 2013). ${ }^{\mathrm{e}}$ Results from Houston in 2000 (Jobson et al., 2004). ${ }^{\mathrm{f}}$ Results from Beijing in 2008-2010 (Liu et al., 2009; Zhang et al., 2012a). ${ }^{\mathrm{g}}$ Emission ratios in Beijing, the northeastern US, Mexico City, and Tokyo (Parrish et al., 2009). ${ }^{\mathrm{h}}$ From a tunnel conducted in Guangzhou (Liu et al., 2008). ${ }^{\mathrm{i}}$ Geometric mean of the ratios in Mexico City in 2003 (Velasco et al., 2007 ). ${ }^{j}$ Results from the northeastern US in 2004 (Warneke et al., 2007). ${ }^{\mathrm{k}}$ Ratios in the winter of 2004 in Tokyo (Shirai et al., 2007).

lated to be in the range $3.47 \times 10^{5}-1.04 \times 10^{6}$ molecules $\mathrm{cm}^{-3}$ on clear days and $6.42 \times 10^{5}-2.35 \times 10^{6}$ molecules $\mathrm{cm}^{-3}$ on haze days. The relatively high $\mathrm{OH}$ concentrations during haze days in winter in Beijing could accelerate oxidation of gas species and further promote formation of secondary particles. The $\mathrm{NO}_{3}$ concentrations were calculated to be in the range from $2.82 \times 10^{9}$ to $4.86 \times 10^{9}$ molecules $\mathrm{cm}^{-3}$ on clear days, which were in good agreement with the maximal value $\left(4.92 \times 10^{9}\right.$ molecules $\left.\mathrm{cm}^{-3}\right)$ reported in Houston dur- ing winter (Asaf et al., 2010). It should be mentioned that the $\mathrm{OH}$ and $\mathrm{NO}_{3}$ derived from the propane / propene ratios could only represent their lower limits because of the continued mixing of fresh emissions with the aged air. 

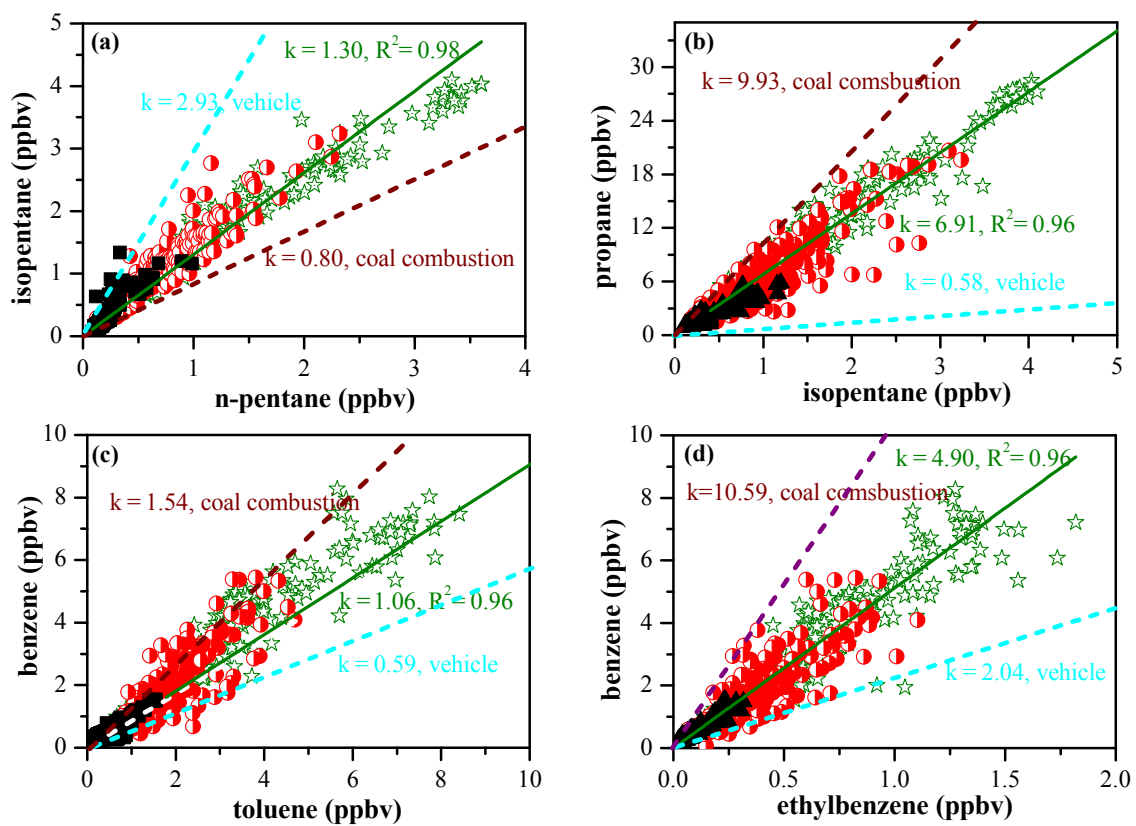

Figure 5. Ratios and linear correlation coefficients $\left(R^{2}\right)$ between (a) isopentane and n-pentane, (b) propane and isopentane, (c) benzene and toluene, and (d) benzene and ethylbenzene during clear days (in black), light haze days (in red), and heavy haze days (in olive).

\subsection{Sources of NMHCs}

\subsubsection{The indicator of typical ratios}

The ratios of o-xylene / m,p-xylene and cis-2-butene / trans2-butene have been widely used as the indicators for gasoline vehicle exhaust emissions (Velasco et al., 2007; Li et al., 2015). As shown in Fig. 4a-b, the slopes (0.36, 0.94) of the linear regressions between the two hydrocarbon pairs of o-xylene / m,p-xylene and trans-2-butene / cis2-butene were in good agreement with the ratios $(0.35$, 1.14) from vehicle emissions (Liu et al., 2008; Wang et al., 2010), implying that vehicle emissions were their dominant source in winter of Beijing. The ratios of propane $/ n-$ butane and propane / isobutane have been frequently used for distinguishing the contributions of gasoline vehicles and the vehicles fueled with LPG (Liu et al., 2008; Lai et al., 2009). The slopes of propane / n-butane (3.12) and propane / isobutane (5.98) both fell between the emission ratios of gasoline vehicles ( 0.49 and 0.74 , respectively) and vehicles using LPG (6.12 and 9.12, respectively), suggesting that emissions from both gasoline and LPG vehicles might be important sources in Beijing. However, the ratios of propane / n-butane (1.65-1.94) and propane / isobutane (1.52-1.97) reported in summer in Beijing (Wang et al., 2010) were much less than the values obtained in this study during wintertime in Beijing. Considering the relatively stable proportion of LPG vehicles to gasoline vehicles during the whole year, additional sources were suspected to make an evident contribution to the relatively high ra- tios of propane / $\mathrm{n}$-butane and propane / isobutane in winter in Beijing. It should be mentioned that the ratios of propane / $\mathrm{n}$-butane and propane / isobutane in winter in Beijing are close to those from domestic coal combustion (4.34 and 8.68, respectively) (Liu et al., 2017), and the ratio (1.92) of isobutane / n-butane was coincident with that from domestic coal combustion (2.0). Therefore, domestic coal combustion around Beijing in winter might make a remarkable contribution to the C3-C4 alkanes. The contribution of domestic coal combustion to atmospheric NMHCs in winter in Beijing could also be confirmed by other ratios of hydrocarbon pairs. As shown in Fig. 5, the ratios of isopenatne /npentane, propane / isopentane, benzene / toluene (B / T), and benzene / ethylbenzene all fell between the emission ratios of vehicles and coal combustion.

In addition to the hydrocarbon pairs above, the slopes of other hydrocarbon pairs were also analyzed and listed in Table 4. With the exception of the hydrocarbon pairs of propane / toluene, propane / isopentane, propane / n-butane, and propane / isobutane, the slopes of other pairs were within the values reported in different cities (Liu et al., 2008; Louie et al., 2013). The slopes for the hydrocarbon pairs of propane / toluene, propane / isopentane, propane / n-butane, and propane / isobutane were remarkably greater than those reported in various cities including Beijing, which were suspected to be from the contribution of domestic coal combustion in winter around Beijing (see discussion above). Barletta et al. (2005) found that the slopes of benzene / acetylene, ethylene / acetylene, and benzene / ethylbenzene in 15 Chinese cities with $\mathrm{B} / \mathrm{T}>1$ were remarkably greater than those 


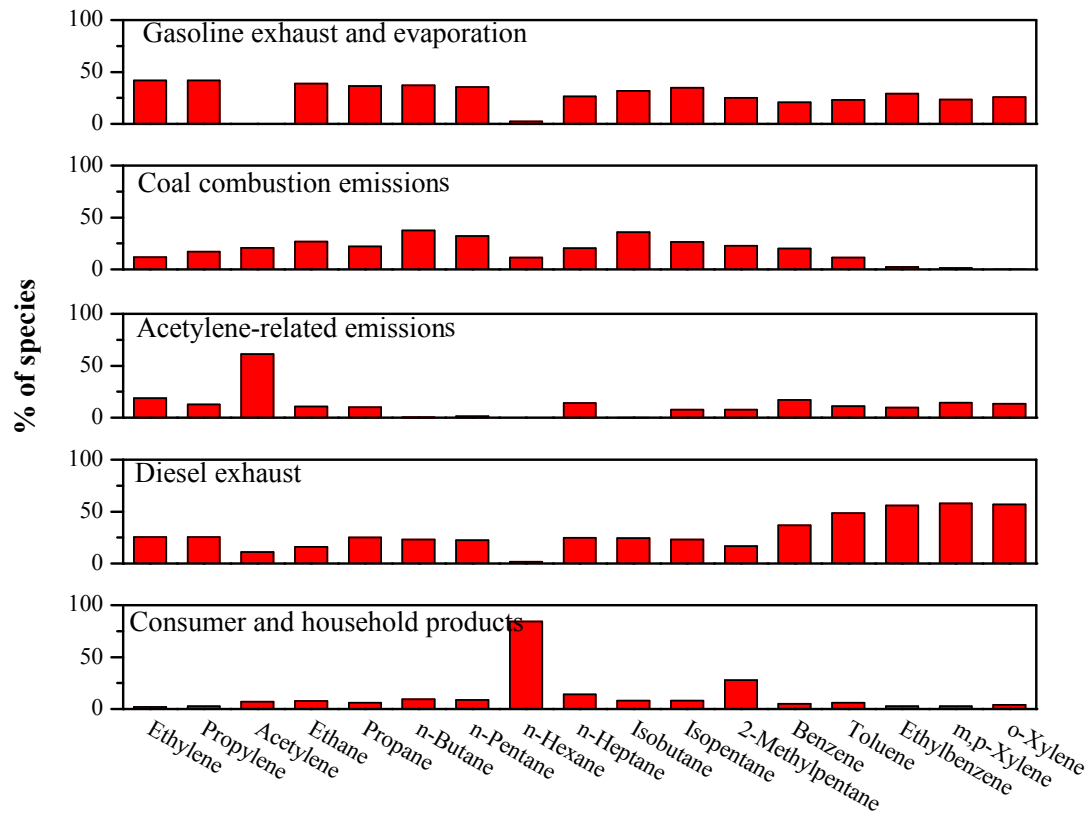

Figure 6. Source profiles (percentage of factor total) resolved from PMF in Beijing.

in 10 Chinese cities (traffic related cities) with a B / T ratio of about 0.6 . They also attributed the relatively high slopes in the 15 Chinese cities to the emissions from biofuel and charcoal combustion. The slopes of benzene / acetylene, ethylene / acetylene, and benzene / ethylbenzene obtained in this study were coincident with those in the 15 cities reported by Barletta et al. (2005), indicating that domestic coal combustion in winter around Beijing might make a contribution to the species. It should be noted that the slopes or the ratios of o-xylene / m,p-xylene and trans-2-butene / cis-2-butene, which have high $\mathrm{OH}$ radical reactivity in various cities, were in good agreement with those of vehicle emissions, whereas the slopes or ratios of the hydrocarbon pairs with low $\mathrm{OH}$ reactivity showed an obvious difference among the cities, implying that the atmospheric NMHCs with high $\mathrm{OH}$ reactivity are dominated by local emissions and the atmospheric NMHCs with low $\mathrm{OH}$ reactivity are strongly influenced by regional transportation.

\subsubsection{The source profiles and apportionments of NMHCs}

The PMF model was performed based on the 740 samples collected and the NMHC species with high uncertainty were excluded to reduce the possible bias of the modeling results. Eventually, 17 NMHC species were selected for the source apportionment analysis since they are the most abundant species and/or are typical tracers of various emission sources. The source appointments of atmospheric NMHCs at the receptor site for the clear days, light haze days, heavy haze days, and all days were separately analyzed by the PMF model, and similar source profiles were found. As shown in Fig. 6 for the whole database, five factors designated as source 1 , source 2 , source 3 , source 4 , and source 5 were resolved from running the PMF model .

Source 1 was characterized by high percentages of iso / $\mathrm{n}$ pentanes, aromatics, and other $\mathrm{C} 2-\mathrm{C} 7$ alkanes. NMHCs from vehicular emissions have been found to be dominated by iso / $\mathrm{n}$-pentanes and aromatics with the benzene/toluene mass ratio of about 0.6 (Barletta et al., 2005), which was in agreement with PMF results for source 1. Additionally, C3-C5 alkanes are also emitted from gasoline evaporations, e.g., isopentane is a typical tracer for gasoline evaporation (Liu et al., 2008). Therefore, source 1 is rationally ascribed to gasoline-related emissions (gasoline exhaust and evaporation).

Source 2 was associated with high percentages of acetylene, C2-C3 alkenes, C2-C5 alkanes, and benzene. It is known that acetylene is a typical species from the combustion process (Barletta et al., 2005; Wu et al., 2016), and high concentrations of $\mathrm{C} 2-\mathrm{C} 3$ alkenes, $\mathrm{C} 2-\mathrm{C} 5$ alkanes, and benzene have been found from resident coal combustion (dos Santos et al., 2004; Liu et al., 2008, 2017). In addition, the ratios of benzene / toluene and propane / isopentane obtained from coal combustion were 1.54-2.22 (Liu et al., 2008) and 8.68 (Liu et al., 2017), respectively, which were close to the ratios in the second source profile. Source 2 has therefore been assigned to coal combustion.

Source 3 was associated with over $60 \%$ of the total measured acetylene, and this source is designated as acetylenerelated emissions. Source 4 was dominated by a high content of toluene, ethylbenzene, and xylenes. It is known that these species can be emitted from coal combustion and ve- 


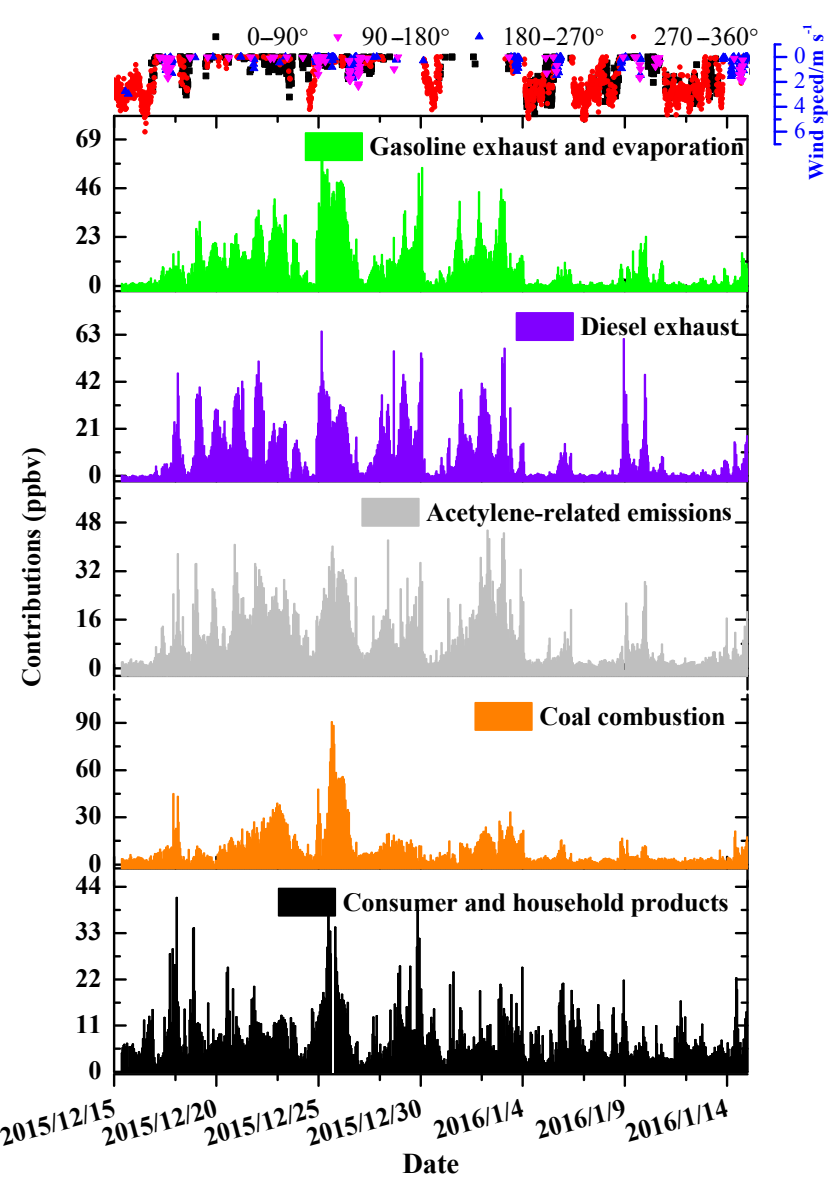

Figure 7. Time series of the contributions from gasoline-related emissions, diesel exhaust, coal combustion, acetylene-related emissions, and consumer and household products to atmospheric NMHCs.

hicular exhaust or be associated with the solvent emissions of paints, inks, sealant, varnish, and thinner for architecture and decoration (Borbon et al., 2002; H. Guo et al., 2011). Coal combustion and gasoline exhaust could be excluded as the main contributors to source 4 because aromatic emissions from the two sources are usually accompanied by high emissions of various species with carbon numbers less than six. Solvent emissions could also be excluded due to the relatively high contribution of small molecules such as ethylene and propene in source 4. Based on the PMF analysis for the diurnal variation characters, source 4 is finally attributed to diesel exhaust.

Source 5 was characterized by high levels of $n$-hexane. $\mathrm{n}$-Hexane is a common constituent of glues used for shoes, leather products, and roofing. Additionally, it is used in solvents to extract oils for cooking and as a cleansing agent for shoes, furniture, and textiles (Kwon et al., 2007; H. Guo et al., 2011). Therefore, this source is categorized under consumer and household products.
The time series of the contributions from the five factors to atmospheric NMHCs are shown in Fig. 7. In general, the variation trends in the contributions from gasolinerelated emissions (gasoline exhaust and evaporation), diesel exhaust, coal combustion emissions, and acetylene-related emissions to atmospheric NMHCs were closely related with the variation trend in atmospheric NMHCs measured, while the contribution from the consumer and household products had less correlation with the atmospheric NMHCs measured. The daily emissions from gasoline-related sources (gasoline exhaust and evaporation), diesel exhaust, coal combustion sources, and acetylene-related sources are usually stable; hence, the similar variation trends in their contributions to atmospheric NMHCs were mainly ascribed to the variation in meteorological condition. The sources of consumer and household products were suspected to be irregular for explaining the abnormal variation trends in their contributions to atmospheric NMHCs. It should be mentioned that the contribution from coal combustion was at a maximum during the most serious pollution episode II (25-26 December 2015), when the wind direction was from the southwest, implying that the air parcel transportation from the south was an important source for NMHCs in Beijing (Wang et al., 2013).

The diurnal variations in the contributions from the five factors to atmospheric NMHCs are shown in Fig. 8. Compared with the sources of coal combustion, acetylene-related emissions, and consumer and household products, the contributions of the vehicle emissions (gasoline and diesel exhaust) to atmospheric NMHCs during the morning and evening rush hours indeed increased during the clear days and light haze days, but the slightly decreased in the morning rush hours during the heavy haze days. The remarkably higher contributions of diesel exhaust than gasoline emissions during the middle of the night for haze days reflected the traffic situation well, namely, heavy diesel vehicles being only permitted on the road during the middle of the night in Beijing. The relatively high contributions of consumer and household products to atmospheric NMHCs mainly occurred on clear days during the daytime when temperature was relatively high. No distinct diurnal variations in the contributions from coal combustion and acetylene-related emissions to atmospheric NMHCs were found.

Figure 8 also shows the individual contributions of the five major NMHC sources to the NMHC concentrations measured on clear days, light haze days, and heavy haze days. It is clear that the contributions of the five major sources in atmospheric NMHCs during the three typical days varied significantly. Gasoline exhaust and evaporation was the largest contributor on clear days, followed by diesel exhaust, coal combustion, acetylene-related emissions, and consumer and household products. Conversely, coal combustion made the largest contribution on haze days, followed by gasoline exhaust and evaporation, diesel exhaust, acetylene-related emissions, and consumer and household products. Considering that the daily emissions of NMHCs from the five ma- 


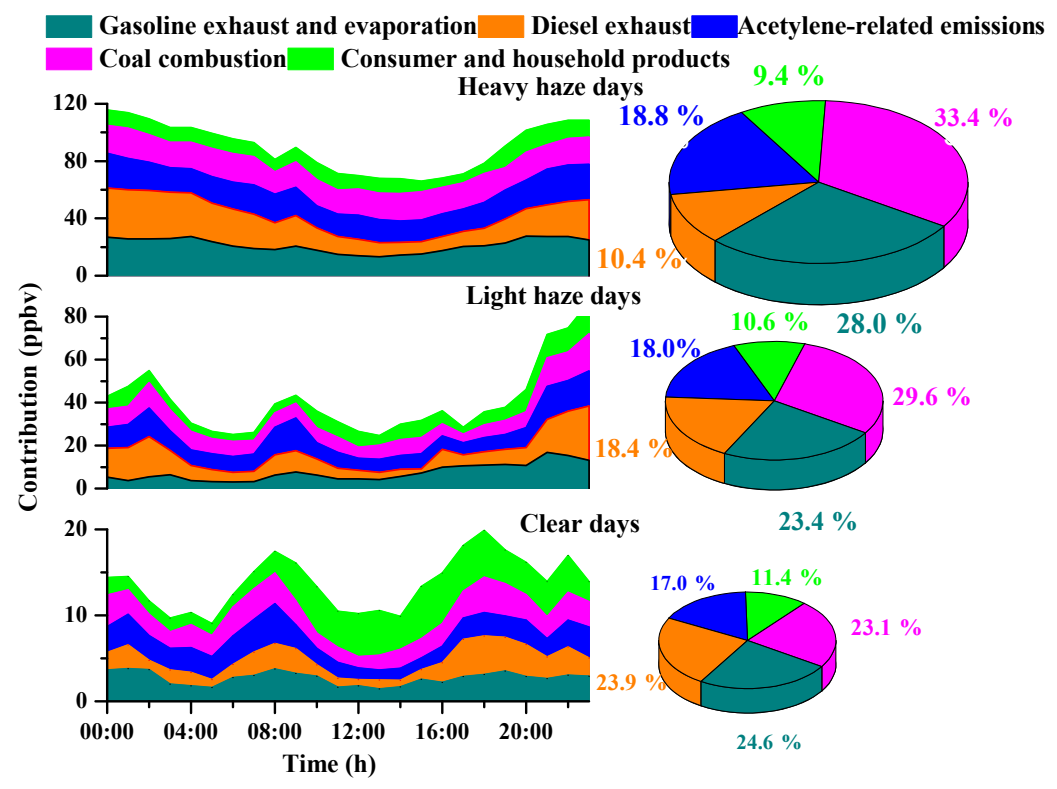

Figure 8. The diurnal variations in the contributions from the five factors to atmospheric NMHCs (left) and source apportionment of NMHCs (right) in Beijing during clear days, light haze days, and heavy haze days.

jor sources were relatively stable during the short period in winter, the distinct variation in the contributions from the five major sources during the three typical days was suspected to be related to the reactivity of the dominant species from each source because of the different $\mathrm{OH}$ concentrations between clear days and haze days (see Sect. 3.2.2). Compared with the species from the other four major sources, the dominant species of toluene, ethylbenzene, and xylene emitted from the diesel exhaust are highly reactive. Hence, a remarkable decrease in the contribution from this source was observed from clear days to haze days. The dominant species of alkanes from coal combustion were relatively stable in comparison with those (alkenes and aromatics) from gasoline exhaust and evaporation, resulting in the fast increase in the contribution from coal combustion from clear days to haze days. Although the central heating stoves that used coal as energy in Beijing have been replaced by relatively clean energies, coal combustion is still an important source of ambient NMHCs during wintertime in Beijing. It should be mentioned that domestic coal combustion is prevalently used for heating and cooking by farmers in rural areas around Beijing city, e.g., the domestic coal consumption accounts for about $11 \%$ of the total in the region of Beijing-Tianjin-Hebei (http://www.qstheory.cn/st/dfst/ 201306/t20130607_238302.htm). Additionally, the emission factors of NMHCs from domestic coal combustion have been found to be a factor of 20 greater than those from coal power plants (Liu et al., 2017). Therefore, the high contribution of coal combustion in Beijing city was mainly attributed to the regional transportation.

\section{Conclusions}

Atmospheric non-methane hydrocarbon compounds were measured at a sampling site in Beijing city from 15 December 2015 to 14 January 2016. The variation trends in NMHC concentrations in Beijing during wintertime were basically identical and exhibited significant fluctuation, which was attributed to the variation in the meteorological conditions. The 10 most prevalent NMHC species during wintertime in Beijing were mainly $\mathrm{C} 2-\mathrm{C} 5$ alkanes, $\mathrm{C} 2-\mathrm{C} 3$ alkenes, acetylene, benzene, and toluene. The remarkable difference of the diurnal variations in alkanes, alkenes, aromatics, and acetylene between clear days and haze days indicated that the relative contribution of the vehicular emissions to atmospheric NMHCs depended on the pollution status. The distinct diurnal variations in the propane / propene ratio indicated that relatively fast consumption of propene by $\mathrm{OH}$ radicals and $\mathrm{O}_{3}$ during the day and by $\mathrm{NO}_{3}$ and $\mathrm{O}_{3}$ at night. The relatively high concentrations of $\mathrm{OH}$ radicals on haze days could accelerate oxidation of gas species and further promote the formation of secondary particles. Both the correlation coefficients of typical hydrocarbon pairs and PMF analysis revealed that coal combustion (probably domestic coal combustion) was an important source for atmospheric NMHCs during wintertime in Beijing, especially on haze days. Therefore, the application of effective control measures for mitigating the serious emissions from prevailingly domestic coal combustion around Beijing in winter is urgent to improve the air quality in Beijing city. 
Data availability. All data described here are available upon request from the corresponding author.

Competing interests. The authors declare that they have no conflict of interest.

Acknowledgements. This work was supported by the National Key R\&D Program of China (2016YFC0202202), the National Natural Science Foundation of China (nos. 91544211, 21477142, 41575121, 41203070), and the Special Fund for Environmental Research in the Public Interest (no. 201509002).

Edited by: Min Shao

Reviewed by: three anonymous referees

\section{References}

An, J., Zhu, B., Wang, H., Li, Y., Lin, X., and Yang, H.: Characteristics and source apportionment of VOCs measured in an industrial area of Nanjing, Yangtze River Delta, China, Atmos. Environ., 97, 206-214, 2014.

Asaf, D., Tas, E., Pedersen, D., Peleg, M., and Luria, M.: Longterm measurements of $\mathrm{NO}_{3}$ radical at a semiarid urban site: 2 . Seasonal trends and loss mechanisms, Environ. Sci. Technol., 44, 5901-5907, 2010.

Atkinson, R.: Kinetics of the gas-phase reactions of $\mathrm{OH}$ radicals with alkanes and cycloalkanes, Atmos. Chem. Phys., 3, 22332307, https://doi.org/10.5194/acp-3-2233-2003, 2003.

Atkinson, R., Baulch, D., Cox, R., Crowley, J., Hampson Jr., R., Kerr, J., Rossi, M., and Troe, J.: Summary of evaluated kinetic and photochemical data for atmospheric chemistry, IUPAC Subcommittee on Gas Kinetic Data Evaluation for Atmos. Chem., available at: http://rpw.chem.ox.ac.uk/IUPACsumm_web_latest. pdf (last access: 5 September 2017), 2001.

Atkinson, R., Baulch, D. L., Cox, R. A., Crowley, J. N., Hampson, R. F., Hynes, R. G., Jenkin, M. E., Rossi, M. J., and Troe, J.: Evaluated kinetic and photochemical data for atmospheric chemistry: Volume $\mathrm{I}-$ gas phase reactions of $\mathrm{O}_{x}, \mathrm{HO}_{x}$, $\mathrm{NO}_{x}$ and $\mathrm{SO}_{x}$ species, Atmos. Chem. Phys., 4, 1461-1738, https://doi.org/10.5194/acp-4-1461-2004, 2004.

Barletta, B., Meinardi, S., Rowland, F. S., Chan, C., Wang, X., Zou, S., Chan, L. Y., and Blake, D. R.: Volatile organic compounds in 43 Chinese cities, Atmos. Environ., 39, 5979-5990, 2005.

Borbon, A., Locoge, N., Veillerot, M., Galloo, J., and Guillermo, R.: Characterisation of NMHCs in a French urban atmosphere: overview of the main sources, Sci. Total Environ., 292, 177-191, 2002.

Daranlot, J., Bergeat, A., Caralp, F., Caubet, P., Costes, M., Forst, W., Loison, J. C., and Hickson, K. M.: Gas-phase kinetics of hydroxyl radical reactions with alkenes: experiment and theory, Chem. Phys. Chem., 11, 4002-4010, 2010.

dos Santos, C. Y. M., de Almeida Azevedo, D., and de Aquino Neto, F. R.: Atmospheric distribution of organic compounds from urban areas near a coal-fired power station, Atmos. Environ., 38, 1247-1257, 2004.
Du, Z., Mo, J., and Zhang, Y.: Risk assessment of population inhalation exposure to volatile organic compounds and carbonyls in urban China, Environ. Int., 73, 33-45, 2014.

Gao, J., Tian, H., Cheng, K., Lu, L., Zheng, M., Wang, S., Hao, J., Wang, K., Hua, S., and Zhu, C.: The variation of chemical characteristics of $\mathrm{PM}_{2.5}$ and $\mathrm{PM}_{10}$ and formation causes during two haze pollution events in urban Beijing, China, Atmos. Environ., 107, 1-8, 2015.

Gaimoz, C., Sauvage, S., Gros, V., Herrmann, F., Williams, J., Locoge, N., Perrussel, O., Bonsang, B., d'Argouges, O., SardaEsteve, R., and Sciare, J.: Volatile organic compounds sources in Paris in spring 2007. Part II: source apportionment using positive matrix factorisation, Environ. Chem., 8, 91-103, 2011.

Goldstein, A. H. and Galbally, I. E.: Known and unexplored organic constituents in the earth's atmosphere, Environ. Sci. Technol., 41, 1514-1521, 2007.

Gros, V., Sciare, J., and Yu, T.: Air-quality measurements in megacities: Focus on gaseous organic and particulate pollutants and comparison between two contrasted cities, Paris and Beijing, C.R. Geosci., 339, 764-774, 2007.

Guo, H., Cheng, H., Ling, Z., Louie, P., and Ayoko, G.: Which emission sources are responsible for the volatile organic compounds in the atmosphere of Pearl River Delta?, J. Hazard. Mater., 188, 116-124, 2011.

Guo, S., Hu, M., Wang, Z. B., Slanina, J., and Zhao, Y. L.: Sizeresolved aerosol water-soluble ionic compositions in the summer of Beijing: implication of regional secondary formation, Atmos. Chem. Phys., 10, 947-959, https://doi.org/10.5194/acp-10-9472010, 2010.

Guo, S., Tan, J., Ma, Y., Yang, F., Yu, Y., and Wang, J.: Characteristics of atmospheric non-methane hydrocarbons during high $\mathrm{PM}_{10}$ episodes and normal days in Foshan, China, Atmos. Res., 101, 701-710, 2011.

Guo, S., Tan, J., Duan, J., Ma, Y., Yang, F., He, K., and Hao, J.: Characteristics of atmospheric non-methane hydrocarbons during haze episode in Beijing, China, Environ. Monit. Assess., 184, 7235-7246, 2012.

Houweling, S., Dentener, F., and Lelieveld, J.: The impact of nonmethane hydrocarbon compounds on tropospheric photochemistry, J. Geophys. Res.-Atmos., 103, 10673-10696, 1998.

Huang, R., Zhang, Y., Bozzetti, C., Ho, K., Cao, J., Han, Y., Daellenbach, K. R., Slowik, J. G., Platt, S. M., and Canonaco, F.: High secondary aerosol contribution to particulate pollution during haze events in China, Nature, 514, 218-222, 2014.

Jia, C., Mao, X., Huang, T., Liang, X., Wang, Y., Shen, Y., Jiang, W., Wang, H., Bai, Z., and Ma, M.: Non-methane hydrocarbons (NMHCs) and their contribution to ozone formation potential in a petrochemical industrialized city, Northwest China, Atmos. Res., 169, 225-236, 2016.

Jobson, B., Berkowitz, C. M., Kuster, W., Goldan, P., Williams, E., Fesenfeld, F., Apel, E., Karl, T., Lonneman, W. A., and Riemer, D.: Hydrocarbon source signatures in Houston, Texas: Influence of the petrochemical industry, J. Geophys. Res.-Atmos., 109, D24305, https://doi.org/10.1029/2004JD004887, 2004.

Kwon, K., Jo, W., Lim, H., and Jeong, W.: Characterization of emissions composition for selected household products available in Korea, J. Hazard. Mater., 148, 192-198, 2007. 
La, Y. S., Camredon, M., Ziemann, P. J., Valorso, R., Matsunaga, A., Lannuque, V., Lee-Taylor, J., Hodzic, A., Madronich, S., and Aumont, B.: Impact of chamber wall loss of gaseous organic compounds on secondary organic aerosol formation: explicit modeling of SOA formation from alkane and alkene oxidation, Atmos. Chem. Phys., 16, 1417-1431, https://doi.org/10.5194/acp16-1417-2016, 2016.

Lai, C., Chang, C., Wang, C., Shao, M., Zhang, Y., and Wang, J.: Emissions of liquefied petroleum gas (LPG) from motor vehicles, Atmos. Environ., 43, 1456-1463, 2009.

Lanz, V. A., Alfarra, M. R., Baltensperger, U., Buchmann, B., Hueglin, C., and Prévôt, A. S. H.: Source apportionment of submicron organic aerosols at an urban site by factor analytical modelling of aerosol mass spectra, Atmos. Chem. Phys., 7, 15031522, https://doi.org/10.5194/acp-7-1503-2007, 2007.

Li, J., Wu, R., Li, Y., Hao, Y., Xie, S., and Zeng, L.: Effects of rigorous emission controls on reducing ambient volatile organic compounds in Beijing, China, Sci. Total Environ., 557-558, 531541,2016

Li, L., Xie, S., Zeng, L., Wu, R., and Li, J.: Characteristics of volatile organic compounds and their role in ground-level ozone formation in the Beijing-Tianjin-Hebei region, China, Atmos. Environ., 113, 247-254, 2015.

Lin, W., Xu, X., Ge, B., and Liu, X.: Gaseous pollutants in Beijing urban area during the heating period 2007-2008: variability, sources, meteorological, and chemical impacts, Atmos. Chem. Phys., 11, 8157-8170, https://doi.org/10.5194/acp-118157-2011, 2011.

Lin, Y., Huang, K., Zhuang, G., Fu, J. S., Wang, Q., Liu, T., Deng, C., and Fu, Q.: A multi-year evolution of aerosol chemistry impacting visibility and haze formation over an Eastern Asia megacity, Shanghai, Atmos. Environ., 92, 76-86, 2014.

Ling, Z. and Guo, H.: Contribution of VOC sources to photochemical ozone formation and its control policy implication in Hong Kong, Environ. Sci. Policy, 38, 180-191, 2014.

Liu, C., Mu, Y., Zhang, C., Zhang, Z., Zhang, Y., Liu, J., Sheng, J., and Quan, J.: Development of gas chromatography-flame ionization detection system with a single column and liquid nitrogenfree for measuring atmospheric C2-C12 hydrocarbons, J. Chromatogr. A, 1427, 134-141, 2016.

Liu, C., Zhang, C., Mu, Y., and Liu, J.: Emission of volatile organic compounds from domestic coal stove with the actual alternation of flaming and smoldering combustion processes, Environ. Pollut., 221, 385-391, 2017.

Liu, J., Mu, Y., Zhang, Y., Zhang, Z., Wang, X., Liu, Y., and Sun, Z.: Atmospheric levels of BTEX compounds during the 2008 Olympic Games in the urban area of Beijing, Sci. Total Environ., 408, 109-116, 2009.

Liu, T., Wang, X., Deng, W., Hu, Q., Ding, X., Zhang, Y., He, Q., Zhang, Z., Lü, S., Bi, X., Chen, J., and Yu, J.: Secondary organic aerosol formation from photochemical aging of lightduty gasoline vehicle exhausts in a smog chamber, Atmos. Chem. Phys., 15, 9049-9062, https://doi.org/10.5194/acp-159049-2015, 2015.

Liu, X. G., Li, J., Qu, Y., Han, T., Hou, L., Gu, J., Chen, C., Yang, Y., Liu, X., Yang, T., Zhang, Y., Tian, H., and Hu, M.: Formation and evolution mechanism of regional haze: a case study in the megacity Beijing, China, Atmos. Chem. Phys., 13, 4501-4514, https://doi.org/10.5194/acp-13-4501-2013, 2013.
Liu, Y., Shao, M., Fu, L. L., Lu, S. H., Zeng, L. M., and Tang, D. G.: Source profiles of volatile organic compounds (VOCs) measured in China: Part I, Atmos. Environ., 42, 6247-6260, 2008.

Louie, P. K., Ho, J. W., Tsang, R. C., Blake, D. R., Lau, A. K., Yu, J. Z., Yuan, Z., Wang, X., Shao, M., and Zhong, L.: VOCs and OVOCs distribution and control policy implications in Pearl River Delta region, China, Atmos. Environ., 76, 125-135, 2013.

Møller, P., Folkmann, J. K., Forchhammer, L., Bräuner, E. V., Danielsen, P. H., Risom, L., and Loft, S.: Air pollution, oxidative damage to DNA, and carcinogenesis, Cancer Lett., 266, 84-97, 2008.

Ou, J., Guo, H., Zheng, J., Cheung, K., Louie, P. K., Ling, Z., and Wang, D.: Concentrations and sources of non-methane hydrocarbons (NMHCs) from 2005 to 2013 in Hong Kong: A multi-year real-time data analysis, Atmos. Environ., 103, 196-206, 2015.

Palm, B. B., Campuzano-Jost, P., Ortega, A. M., Day, D. A., Kaser, L., Jud, W., Karl, T., Hansel, A., Hunter, J. F., Cross, E. S., Kroll, J. H., Peng, Z., Brune, W. H., and Jimenez, J. L.: In situ secondary organic aerosol formation from ambient pine forest air using an oxidation flow reactor, Atmos. Chem. Phys., 16, 2943 2970, https://doi.org/10.5194/acp-16-2943-2016, 2016.

Pang, X. and Mu, Y.: Seasonal and diurnal variations of carbonyl compounds in Beijing ambient air, Atmos. Environ., 40, 63136320, 2006.

Parrish, D. D., Kuster, W. C., Shao, M., Yokouchi, Y., Kondo, Y., Goldan, P. D., de Gouw, J. A., Koike, M., and Shirai, T.: Comparison of air pollutant emissions among mega-cities, Atmos. Environ., 43, 6435-6441, 2009.

Quan, J., Gao, Y., Zhang, Q., Tie, X., Cao, J., Han, S., Meng, J., Chen, P., and Zhao, D.: Evolution of planetary boundary layer under different weather conditions, and its impact on aerosol concentrations, Particuology, 11, 34-40, 2013.

Rappenglück, B., Ackermann, L., Alvarez, S., Golovko, J., Buhr, M., Field, R. A., Soltis, J., Montague, D. C., Hauze, B., Adamson, S., Risch, D., Wilkerson, G., Bush, D., Stoeckenius, T., and Keslar, C.: Strong wintertime ozone events in the Upper Green River basin, Wyoming, Atmos. Chem. Phys., 14, 4909-4934, https://doi.org/10.5194/acp-14-4909-2014, 2014.

Shao, M., Zhao, M., Bai, Y., Li, J., and Tang, X.: Study on emission characteristics of nonmethane hydrocarbons from anthropogenic sources in the atmosphere of Beijing, China Environ. Sci., 14, 6-12, 1994.

Shao, P., An, J., Xin, J., Wu, F., Wang, J., Ji, D., and Wang, Y.: Source apportionment of VOCs and the contribution to photochemical ozone formation during summer in the typical industrial area in the Yangtze River Delta, China, Atmos. Res., 176, 64-74, 2016.

Shen, X., Zhao, Y., Chen, Z., and Huang, D.: Heterogeneous reactions of volatile organic compounds in the atmosphere, Atmos. Environ., 68, 297-314, 2013.

Shi, G. L., Li, X., Feng, Y. C., Wang, Y. Q., Wu, J. H., Li, J., and Zhu, T.: Combined source apportionment, using positive matrix factorization-chemical mass balance and principal component analysis/multiple linear regression-chemical mass balance models, Atmos. Environ., 43, 2929-2937, 2009. 
Shirai, T., Yokouchi, Y., Blake, D. R., Kita, K., Izumi, K., Koike, M., Komazaki, Y., Miyazaki, Y., Fukuda, M., and Kondo, Y.: Seasonal variations of atmospheric C2-C7 nonmethane hydrocarbons in Tokyo, J. Geophys. Res.-Atmos., 112, D24305, https://doi.org/10.1029/2006JD008163, 2007.

Song, P., Geng, F., Sang, X., Chan, C., Chan, L., and Yu, Q.: Characteristics and sources of non-methane hydrocarbons and halocarbons in wintertime urban atmosphere of Shanghai, China, Environ. Monit. Assess., 184, 5957-5970, 2012.

Song, Y., Shao, M., Liu, Y., Lu, S., Kuster, W., Goldan, P., and Xie, S.: Source apportionment of ambient volatile organic compounds in Beijing, Environ. Sci. Technol., 41, 4348-4353, 2007.

Sowlat, M. H., Hasheminassab, S., and Sioutas, C.: Source apportionment of ambient particle number concentrations in central Los Angeles using positive matrix factorization (PMF), Atmos. Chem. Phys., 16, 4849-4866, https://doi.org/10.5194/acp16-4849-2016, 2016.

Srivastava, A., Sengupta, B., and Dutta, S.: Source apportionment of ambient VOCs in Delhi City, Sci. Total Environ., 343, 207-220, 2005.

Sun, J., Wu, F., Hu, B., Tang, G., Zhang, J., and Wang, Y.: VOC characteristics, emissions and contributions to SOA formation during hazy episodes, Atmos. Environ., 141, 560-570, 2016.

Sun, Y., Jiang, Q., Wang, Z., Fu, P., Li, J., Yang, T., and Yin, Y.: Investigation of the sources and evolution processes of severe haze pollution in Beijing in January 2013, J. Geophys. Res.-Atmos., 119, 4380-4398, 2014.

US EPA (Compliance and Innovative Strategies Division, Office of Transportation and Air Quality): Fuel Trends Report, Gasoline 1995-2005, EPA420-R-08-002, 2008.

Velasco, E., Lamb, B., Westberg, H., Allwine, E., Sosa, G., ArriagaColina, J. L., Jobson, B. T., Alexander, M. L., Prazeller, P., Knighton, W. B., Rogers, T. M., Grutter, M., Herndon, S. C., Kolb, C. E., Zavala, M., de Foy, B., Volkamer, R., Molina, L. T., and Molina, M. J.: Distribution, magnitudes, reactivities, ratios and diurnal patterns of volatile organic compounds in the Valley of Mexico during the MCMA 2002 \& 2003 field campaigns, Atmos. Chem. Phys., 7, 329-353, https://doi.org/10.5194/acp-7329-2007, 2007.

Volkamer, R., Jimenez, J. L., San Martini, F., Dzepina, K., Zhang, Q., Salcedo, D., Molina, L. T., Worsnop, D. R., and Molina, M. J.: Secondary organic aerosol formation from anthropogenic air pollution: Rapid and higher than expected, Geophys. Res. Lett., 33, L17811, https://doi.org/10.1029/2006GL026899, 2006.

Waked, A., Afif, C., and Seigneur, C.: An atmospheric emission inventory of anthropogenic and biogenic sources for Lebanon, Atmos. Environ., 50, 88-96, 2012.

Waked, A., Sauvage, S., Borbon, A., Gauduin, J., Pallares, C., Vagnot, M.-P., Léonardis, T., and Locoge, N.: Multi-year levels and trends of non-methane hydrocarbon concentrations observed in ambient air in France, Atmos. Environ., 141, 263-275, 2016.

Wang, B., Shao, M., Lu, S. H., Yuan, B., Zhao, Y., Wang, M., Zhang, S. Q., and $\mathrm{Wu}, \mathrm{D}$.: Variation of ambient non-methane hydrocarbons in Beijing city in summer 2008, Atmos. Chem. Phys., 10, 5911-5923, https://doi.org/10.5194/acp-10-5911-2010, 2010.

Wang, M., Shao, M., Lu, S., Yang, Y., and Chen, W.: Evidence of coal combustion contribution to ambient VOCs during winter in Beijing, Chin. Chem. Lett., 24, 829-832, 2013.
Wang, M., Shao, M., Chen, W., Lu, S., Liu, Y., Yuan, B., Zhang, Q., Zhang, Q., Chang, C.-C., Wang, B., Zeng, L., Hu, M., Yang, Y., and Li, Y.: Trends of non-methane hydrocarbons (NMHC) emissions in Beijing during 2002-2013, Atmos. Chem. Phys., 15, 1489-1502, https://doi.org/10.5194/acp-15-1489-2015, 2015.

Wang, Y., Ren, X., Ji, D., Zhang, J., Sun, J., and Wu, F.: Characterization of volatile organic compounds in the urban area of Beijing from 2000 to 2007, J. Environ. Sci., 24, 95-101, 2012.

Warneke, C., McKeen, S., De Gouw, J., Goldan, P., Kuster, W., Holloway, J., Williams, E., Lerner, B., Parrish, D., and Trainer, M.: Determination of urban volatile organic compound emission ratios and comparison with an emissions database, J. Geophys. Res.-Atmos., 112, D10S47, https://doi.org/10.1029/2006JD007930, 2007.

Wegener, R., Brauers, T., Koppmann, R., Rodríguez Bares, S., Rohrer, F., Tillmann, R., Wahner, A., Hansel, A., and Wisthaler, A.: Simulation chamber investigation of the reactions of ozone with short-chained alkenes, J. Geophys. Res.-Atmos., 112, D13301, https://doi.org/10.1029/2006JD007531, 2007.

Wu, R., Li, J., Hao, Y., Li, Y., Zeng, L., and Xie, S.: Evolution process and sources of ambient volatile organic compounds during a severe haze event in Beijing, China, Sci. Total Environ., 560, 62-72, 2016.

Xie, S. D., Liu, Z., Chen, T., and Hua, L.: Spatiotemporal variations of ambient $\mathrm{PM}_{10}$ source contributions in Beijing in 2004 using positive matrix factorization, Atmos. Chem. Phys., 8, 27012716, https://doi.org/10.5194/acp-8-2701-2008, 2008.

Yang, F., Chen, H., Du, J., Yang, X., Gao, S., Chen, J., and Geng, F.: Evolution of the mixing state of fine aerosols during haze events in Shanghai, Atmos. Res., 104, 193-201, 2012.

Yuan, B., Chen, W., Shao, M., Wang, M., Lu, S., Wang, B., Liu, Y., Chang, C., and Wang, B.: Measurements of ambient hydrocarbons and carbonyls in the Pearl River Delta (PRD), China, Atmos. Res., 116, 93-104, 2012.

Zhang, H., Xu, X., Lin, W., and Wang, Y.: Wintertime peroxyacetyl nitrate (PAN) in the megacity Beijing: Role of photochemical and meteorological processes, J. Environ. Sci.-China, 26, 83-96, 2014.

Zhang, R., Jing, J., Tao, J., Hsu, S.-C., Wang, G., Cao, J., Lee, C. S. L., Zhu, L., Chen, Z., Zhao, Y., and Shen, Z.: Chemical characterization and source apportionment of $\mathrm{PM}_{2.5}$ in Beijing: seasonal perspective, Atmos. Chem. Phys., 13, 7053-7074, https://doi.org/10.5194/acp-13-7053-2013, 2013.

Zhang, Y., Mu, Y., Liang, P., Xu, Z., Liu, J., Zhang, H., Wang, X., Gao, J., Wang, S., and Chai, F.: Atmospheric BTEX and carbonyls during summer seasons of 2008-2010 in Beijing, Atmos. Environ., 59, 186-191, 2012a.

Zhang, Y. J., Mu, Y., Liu, J., and Mellouki, A.: Levels, sources and health risks of carbonyls and BTEX in the ambient air of Beijing, China, J. Environ. Sci., 24, 124-130, 2012b.

Zhang, Y. J., Mu, Y., Meng, F., Li, H., Wang, X., Zhang, W., Mellouki, A., Gao, J., Zhang, X., and Wang, S.: The pollution levels of BTEX and carbonyls under haze and non-haze days in Beijing, China, Sci. Total Environ., 490, 391-396, 2014.

Zheng, G. J., Duan, F. K., Su, H., Ma, Y. L., Cheng, Y., Zheng, B., Zhang, Q., Huang, T., Kimoto, T., Chang, D., Pöschl, U., Cheng, Y. F., and He, K. B.: Exploring the severe winter haze in Beijing: the impact of synoptic weather, regional transport and 
heterogeneous reactions, Atmos. Chem. Phys., 15, 2969-2983, https://doi.org/10.5194/acp-15-2969-2015, 2015.

Zhou, J., You, Y., Bai, Z., Hu, Y., Zhang, J., and Zhang, N.: Health risk assessment of personal inhalation exposure to volatile organic compounds in Tianjin, China, Sci. Total Environ., 409, 452-459, 2011.
Zou, Y., Deng, X. J., Zhu, D., Gong, D. C., Wang, H., Li, F., Tan, H. B., Deng, T., Mai, B. R., Liu, X. T., and Wang, B. G.: Characteristics of 1 year of observational data of $\mathrm{VOC}_{s}, \mathrm{NO}_{x}$ and $\mathrm{O}_{3}$ at a suburban site in Guangzhou, China, Atmos. Chem. Phys., 15, 6625-6636, https://doi.org/10.5194/acp-15-6625-2015, 2015. 